KEYWORDS

Technological innovations

Research and development

Industrial enterprises

Data analysis

Mathematical models

Argentina

Brazil
Eduardo Gonçalves

Professor of the Faculty of

Economics and Administration

Federal University of J uiz de Fora

J uiz de Fora, Minas Gerais

Brazil

• eduardo.goncalves@ufjf.edu.br

Mauro Borges Lemos

Professor of the Centre for Regional

Development and Planning

Faculty of Economic Sciences

Federal University of Minas Gerais

Belo Horizonte, Minas Gerais

Brazil

œmbl@cedeplar.ufmg.br

J oão de Negri

Institute of Applied Economic

Research (IPEA)

Brasilia, D.F.

Brazil

$\leadsto$ denegri@ipea.gov.br

\section{Determinants of technological innovation in Argentina and Brazil}

E duardo G onçalves, M auro B orges L emos and João de N egri

$\mathrm{T}$

his article analyses and compares the determinants of innovation in Argentina and Brazil, countries that have based their industrialization strategies on import substitution. Probit regressions in which instrumental variables are used to check for problems of endogeneity of exports reveal that, in both countries, knowledge external to firms helps to promote innovation, that internal research and development capacity is relatively weak and that external trade integration has a positive effect on firms' propensity to innovate (more so in Brazil than in Argentina). The results of this study suggest in general that there has been modest progress in the pattern of innovation among Argentine and Brazilian firms in recent years compared with the import substitution period. 
I

\section{Introduction}

Innovation is generally considered to be one of the main drivers of economic development (Rosenberg, 1976). The underdevelopment of Latin American countries is therefore frequently attributed to problems with their import substitution-based industrialization process, which has resulted in sectorally fragile production structures and a heterogeneous mix of industrial firms. Although Argentina and Brazil have progressed with industrialization compared with other Latin American countries -especially as regards sectoral diversificationboth countries' industrial structures show marked fragility and heterogeneity. According to Teitel and Thoumi (1986), the import substitution processes in Argentina and Brazil were very similar.

The first phase in these two countries' import substitution processes extends from the early twentieth century until the Second World War, with the development of industries for non-durable consumer goods (such as food products) and simple consumer goods (such as furniture, wearing apparel, footwear, farm equipment and tools). The first phase is deemed to have arisen from growth in the consumer market and from agricultural sector surpluses, especially in Brazil's coffee sector and Argentina's beef and cereal sectors.

In the second phase, extending from the 1950s until the early 1970s, both countries consolidated their production capacity for durable consumer goods, as well as their industrial complex for the manufacture of basic metals and fabricated metal products. This phase was characterized by iron and steel intermediate goods and finished products such as refrigerators, washing machines, motorcycles and, later, cars and trucks. Both countries also began to manufacture some machinetools and industrial equipment.

The third and final phase began in the mid-1960s and lasted until the late 1970s. It was characterized by the integration and strengthening of the basic chemical industry, the metallurgical industry, the pulp and paper industry and other intermediate goods industries, as well

$\square$ The authors are grateful to an anonymous CEPAL Review referee for his comments and suggestions, which did much to improve the final version of the article. The authors take full responsibility for any errors or omissions. as industries manufacturing larger and more complex capital goods. However, a number of analyses have highlighted the limited and incomplete nature of this phase (Furtado, 1968; Tavares, 1978; Rodrigues, 1981; Mello, 1982), which gave rise to sectoral weaknesses in the industrialization process.

According to Bell and Pavitt (1993), in Latin American countries the development of the capital goods industry and of large-scale manufacturing sectors was not followed by the emergence of sectors manufacturing specialized and complex instruments or machinery, or making intensive use of knowledge. This belated and incomplete industrialization process has had a direct impact on the innovative capacity of the Argentine and Brazilian economies.

According to Ranis (1984), the import substitution policy adversely affected local technological activity because it prompted firms to acquire the technology available in the world market. Focusing on physical accumulation rather than on efficiency posed the problem of choosing appropriate technologies. Furthermore, as the tariff protection system distorted the prices of factors and products, it created windfall profits for the entrepreneurial class, which lost interest in seeking local technological opportunities. The import substitution model also encouraged the free entry of capital goods, whilst affording tariff protection to the intermediate and finished goods segments.

This type of criticism of import substitution policies so common in specialized literature can be more aptly applied to the model adopted by Latin American countries, where the factors and conditions for reciprocity of support to infant industry tended to be weak or non-existent. As Okimoto (1989) and Amsden (1989) pointed out, the experiences of southeast Asian countries (especially the Republic of Korea and Japan) show that the establishment of reciprocity rules on performance (in innovation and exports) and on timeframes (for the duration of the support and compliance with the reciprocity rules) allows the successive phases of import substitution and export substitution to be synchronized to build the structural foundations for long-term growth.

Lack of synchronization in the substitution dynamic perpetuates the weakness or non-existence of the capital goods industry in developing countries 
because it limits opportunities to introduce capitalintensive innovations and hinders the development of the technology base of skills, knowledge, infrastructure and organization on which technical progress relies.

According to Rosenberg (1976), the machine-tools sector is decisive in the creation and dissemination of new skills and techniques in an economy. These are developed and perfected in response to demand from specific customers and are later passed on to all sectors that use machinery. The capital goods sector is also crucial to making any sort of innovation viable, in products or processes, because a new capital good with defined specifications will need to be produced for every new consumer good planned for manufacture.

Unless the State acts to instigate and guide the industrialization process in developing countries, a condition of technological dependence is reproduced, with the result that almost all types of innovation introduced in developing countries are to improve or perfect existing processes or products (Fransman, 1985). In contrast, developed countries tend to spearhead all radical Schumpeterian-type technological changes. To enable them to join the radical technology innovators, countries that are striving to catch up with more advanced nations need to implement specific policies of new-technology training, coordinated with the substitution model dynamic. There is a major difference between Asian and Latin American countries in terms of import-substitutive industrialization.

These distinctive features of the process of technological change in Latin American countries, stemming from their chosen import substitution model, have led international technology transfer mechanisms to take on crucial importance for those countries. Examples include foreign direct investment (FDI), the import of capital goods, licensing and know-how agreements, and technical assistance.

The effects of the foreign-technology absorption process on local capacity to develop technology vary because they depend on the form and degree of dependence entailed by technology imports (Lall, 1992). Lall believes that technology imports must nurture local technology effort and never suppress it. Otherwise the presence of subsidiaries of multinationals could be detrimental, given the tendency of multinational companies to keep their research and development (R\&D) functions at head office. Licensing and outside consulting can also be damaging if know-how is not transferred to local agents. Special, functional and selective measures are therefore needed to develop local technological capacity.
Dahlman (1984) took a similar stance by stressing the difference between acquiring technological capacity and acquiring technology. While technology can be acquired by means of foreign direct investment, licences, know-how transfer, technical service agreements and imports of capital, technological capacity can be developed only by training human capital, which calls for formal education, in-service training, experience and special efforts to obtain, assimilate, adapt, improve or create new technology. This requires a country acquiring technology to gear its approach to the level of learning involved in the technology transfer. This level of learning is understood to mean the acquisition of additional knowledge and technical skills by individuals and organizations (Bell, 1984).

Experiences of industrialization in Latin America show that the tendency to acquire technology rather than technological capacity even extended to the major economies. The Argentine and Brazilian cases are paradigmatic (Katz and Bercovich, 1993; Dahlman and Frischtak, 1993). When the import substitution model failed, the ability to develop national technological capacity was thwarted by the institutional changes that occurred in Argentina and Brazil, as well as in other Latin American economies, in the 1980s and 1990s.

Cimoli and Katz (2001) highlight the effects of adjustments in regional economies following recent processes of trade liberalization and market deregulation arising from globalization. The result of some structural changes in the world economy (with the increasing returns to scale in the production of knowledge and synergies and the interdependence of firms and other institutions that globalization tends to produce) was a trend towards the concentration of research and development and engineering activities in mature countries. Moreover, the developing economies specialized in low value-added commodities and in assembly or maquiladora (or in-bond) activities. In the case of Argentina, some production changes led to the destruction of human capital and technological capacities and their substitution by capital incorporating new technology, as well as by foreign engineering and research and development services.

Given that Argentina and Brazil's industrial structures reflect the legacy of the import substitution period and the effects of macroeconomic adjustment starting in the 1990s, this article sets out to make a comparative assessment of the current determinants of technological innovation in industrial firms in the two countries. The study focuses on company's internal determinants related to the efforts it makes to 
innovate through spending on $R \& D$, purchasing $R \& D$ from other companies, buying R\&D from other firms, acquiring machinery and equipment, and expenditure on industrial projects and other external knowledge.

\section{II}

\section{Methodology}

\section{Description of databases and construction of variables}

The data on innovative activities in Brazil come from the Industry Technological Innovation Survey (PINTEC), which covers innovations introduced during the period 1998-2000. This survey includes firms with more than 10 employees and was conducted by the Brazilian Geographical and Statistical Institute (IBGE, 2002). PINTEC follows the Oslo Manual of the Organization for Economic Co-operation and Development (OECD) and the methodology of the third Community Innovation Survey 1998-2000 (CIS3), in which 15 European Union countries participated. Data were also drawn from the Annual Industrial Survey (Pesquisa Industrial Anual - PIA) from IBGE, the Foreign Capital Census from the Central Bank (BACEN), and external trade data from the Foreign Trade Department of the Ministry of Development, Industry, and Trade.

The data for Argentina are drawn from the second National Survey on Innovation and Technological Behaviour in Argentine Firms (Encuesta Nacional de Innovación y Conducta Tecnológica de las Empresas Argentinas) for the period 1998-2001, conducted by the National Institute of Statistics and Censuses (INDEC). This survey follows the methodology suggested by the Statistical Office of the European Communities (EUROSTAT) and the Oslo, Frascati and Bogotá manuals (INDEC/SECYT/ECLAC, 2003).

The reference year for the innovation variables is 2000 in the case of Brazil and 2001 in the case of Argentina. The regressions were calculated using the expanded number of firms in the samples, which represent the universe of industrial firms in the two countries.

A comparison of the two surveys poses two problems. ${ }^{1}$ The first is the period covered by the data

\footnotetext{
${ }^{1}$ This paragraph is based entirely on the comments of an anonymous CEPAL Review referee, who warned the authors of these problems and to whom the authors are very grateful.
}

Section II below details the methodology and databases used. Section III shows the results of the regressions for Argentina and Brazil, and section IV presents the conclusions of the study. derived from answers to the respective questionnaires. Whereas the Argentine survey analyses the introduction of innovations in the previous four years, the Brazilian survey covers the previous three years. If innovation is assumed to be a random variable distributed uniformly over the period in question, we could conclude that the Argentine data are overestimated by $25 \%$ compared with the Brazilian data. The second, even more serious, problem relates to the structure of the samples. The National Survey on Innovation and Technological Behaviour in Argentine Firms is a sample of the annual industrial survey. By contrast, the Brazilian survey is not a random sample of registered manufacturing firms. This industrial survey overestimates large firms. Bearing in mind that size is a positive factor for innovation, this bias leads to an overestimation of new innovations in the Argentine survey compared with PINTEC. In other words, the two problems together result in an overestimate of data on Argentine innovation, which limits the usefulness of comparing the descriptive statistics of the two surveys.

However, we believe that these biases do not compromise the results of the regressions, because the two databases were not combined. The regression equations were constructed separately and the results were compared later. As regards the first bias (the period for which information was obtained), it is highly unlikely that a one-year difference would affect the distribution of the determinants of innovative effort. As regards the second bias (the overestimation of Argentine large firms), the introduction of the dummy variable 'company size' as a control variable may have sufficed to resolve the problem.

Setting aside these points, the database indicators reveal that $56 \%$ of Argentine firms introduced some type of technological innovation in the period 19982001 (INDEC-SECYT-ECLAC, 2003) and that $31.8 \%$ of Brazilian firms did so in the period 1998-2000 (IBGE, 2002). The 2,541 Argentine firms that introduced new products onto the market represent around $21 \%$ 
of the universe of Argentine firms $(11,720)$, whereas the 2,938 Brazilian firms which the 1998-2000 survey considered to have introduced innovative products into the domestic market represented around 4\%.

One of the virtues of the two surveys is that they take into account not only expenditure on research and development but also expenditure on other types of innovative activity. Box 1 compares and correlates the methodologies of the two surveys with reference to the definitions of innovative activities used in the questionnaires. Even though the Argentine survey contained no questions concerning expenditure for introducing innovations onto the market and the Brazilian questionnaire contained no questions concerning management and consulting expenditure, the other items are fairly well matched, as the box illustrates.

In Brazil, expenditure on the acquisition of machinery and equipment predominates, representing around $52.1 \%$ of innovation expenditure in 2000. Spending on research and development represented $16.8 \%$ and on industrial projects and other technical systems, $14.8 \%$. The rest of the expenditure was for the introduction of technological innovations into the market $(6.4 \%)$, the acquisition of other external knowledge $(5.2 \%)$, the external acquisition of R\&D $(2.8 \%)$ and training $(1.9 \%)$.

In Argentina, expenditure on machinery and equipment totalled $75 \%$ of innovation spending in 2000. Expenditure on research and development activities represented $8.6 \%$ and on technology transfer,
$6.5 \%$. The rest was divided among engineering and industrial design $(3.6 \%)$, training $(1.8 \%)$, consulting $(1.7 \%)$, management $(1.5 \%)$ and the purchase of R\&D (1.3\%).

Apart from variables for different types of innovation expenditure and the number of employees assigned to research and development activities, this article also included control variables such as external trade integration (import and export coefficients) and structural and performance variables (degree of market concentration and productivity rate). It also included structural dummy variables to capture the different sectoral trends in innovation and the influence of company size and of the source of capital. The Central Bank of Brazil defines a firm with a foreign source of capital as one with more than $50 \%$ of its capital controlled by foreigners. A dummy variable was created that took the value 'one' if the firm was a multinational and 'zero' if it was domestic. The firms were classified into three groups according to size: microenterprises and small enterprises (between 10 and 99 employees), which was used as the reference category; mediumsized enterprises (between 100 and 499 employees) and large enterprises (more than 500 employees).

The various types of expenditure on innovation (internal research and development effort, purchase of R\&D, expenditure on other external knowledge, on machinery and equipment and on industrial projects) were divided by the firm's total expenditure on innovation. The data are for the year 2000.

Box 1

ARGENTINA AND BRAZIL: DEFINITIONS OF INNOVATIVE ACTIVITIES IN THE TWO NATIONAL SURVEYS

\begin{tabular}{ll}
\hline Brazil & Argentina \\
\hline Research and development & Research and development \\
External acquisition of research and development & External research and development \\
Acquisition of other external knowledge & Technology transfer \\
Acquisition of machinery and equipment & Acquisition of capital goods, hardware and/or software \\
Training & Training \\
Industrial projects and other technical systems & Engineering and industrial design \\
Introduction of technological innovations into the market & $\ldots$ \\
$\ldots$ & Management \\
$\ldots$ & Consulting \\
\hline
\end{tabular}

Source: IBGE (2002); INDEC/SECYT/ECLAC (2003). 
The research and development intensity indicator was constructed by dividing a firm's research and development expenditure by its total sales revenue in 2000. The proportion of personnel assigned to research and development was calculated by dividing the number of employees working in research and development activities by the firm's total number of employees in 2000.

The other three variables were constructed with a two-year lag compared with the dependent variables in the study, which are new products and processes introduced into the market. This was done to avoid problems of endogeneity between the regressors and the dependent variable. The import coefficient, productivity and market concentration therefore all refer to the year 1998.

The import coefficient was constructed by dividing a firm's imports by its total sales revenue. The productivity variable was calculated by dividing a firm's total sales revenue by the number of employees. The concentration variable, measured in percentages, was calculated by dividing the total sales revenue of the firm (i) in the sector (j) by the total sales revenue of the sector $(\mathrm{j})$ (classified in accordance with the CNAE, Brazil's standard two-digit national classification of economic activities (Classificação Nacional de Atividades Econômicas). ${ }^{2}$

The construction of time-lagged variables was not sufficient to resolve the problem of endogeneity in the export coefficient variable. In this case, the probit model $^{3}$ reveals results in which the export coefficient variable has a sign opposite to the one expected or lacks statistical significance. This contradicts the empirical tests and the theoretical argument that exports are an important mechanism for stimulating innovation.

Indeed, the theoretical reasons for distrusting the negative sign of the export coefficient can be found in studies linking export capacity with innovation (De Negri and Salermo, 2005; Chudnovsky, López and Orlicki, 2005) and studies demonstrating the influence of innovation on exports (Pamukcu, 2003). The specific case of the non-significance of export intensity for innovation is also supported by empirical literature. Where firms do not learn about export activities, past export performance makes no contribution at all to future export performance, as Bernard and Jensen point out (1999). ${ }^{4}$

\footnotetext{
${ }^{2}$ See footnote 7 below for information on the CNAE.

${ }^{3}$ Probit models are models with discrete variables based on a cumulative normal distribution function.

${ }^{4}$ This point was added to the text based on the observation of an anonymous CEPAL Review referee.
}

The probit model was therefore implemented using endogenous regressors. ${ }^{5}$ The export coefficient was constructed by dividing firms' exports in the year 2000 (in the case of Argentina, the data were for 2001) by firms' sales revenue in that year.

Two instrumental variables were used for the export coefficient variable. The instrumental variable used for Brazil was the export pattern of firms, whose export values were weighted by the gross domestic product (GDP) growth rate of the export destination country in the period 1997-2000. The second instrument was a dummy variable indicating whether or not a firm had exported prior to 1997.

In the case of Argentina, the only data available was sector-specific data on exports to two destinations (Brazil and the rest of the world). By contrast, Brazilian export data were available for individual firms and for exports to a number of destinations, by crossing data from the Secretariat of Foreign Trade, the PINTEC industry technological innovation survey and the PIA annual industry survey of firms. So, in addition to the GDP growth rates of these two export destinations, the fact of whether or not an Argentine firm had exported in 1998 was also included as an instrumental variable. Argentina's export coefficient variable refers to the year 2001.

The use of these instruments is warranted for three reasons. The first is that they are totally exogenous with respect to the variables used in the econometric specification. The second reason, specific to the application of the time-lagged dummy variable of 'export status' (having, or not having, exported), is the likelihood of export inertia, which tends to be an exogenous factor strongly correlated with the export coefficient. The third reason is that these instruments have proven to be effective, as demonstrated by the results of the tests described in the next section. The validity of the two instrumental variables used was tested using Shea's partial $\mathrm{R}^{2}$ (1997) to verify the statistical significance and explanatory power of each of these instruments, together with the Sargan test, which proved that the instruments were strongly correlated with the potentially endogenous variable and were not correlated with the error terms.

There is a low level of correlation among the independent variables themselves, which is necessary to avoid problems of multicollinearity. Appendix A

\footnotetext{
5 The STATA data analysis and statistical software programme was used to implement this method.
} 
(tables A.1 and A.2) shows the correlation matrix of the samples.

\section{Econometric method}

The effects of the variables for measuring structural and performance characteristics and types of innovation expenditure on the propensity of firms to innovate were calculated using a probit model (Greene, 2003). To counter any endogeneity between a regressor and the error term, the method of applying instrumental variables to the probit model was also used (probit model with endogenous regressors). ${ }^{6}$ In addition to the theoretical justification for the existence of a dual causality relationship between innovation and exports, a set of tests was used to evaluate the suspicion of endogeneity and the suitability of the instruments employed.

The first is the Wald test of exogeneity of the instrumental variable. If the Wald statistic is not significant, there is not enough information in the sample to reject the null hypothesis of exogeneity. In that case, the basic probit model suffices (STATA, 2005). The test is $\chi^{2}$ distributed with one degree of freedom.

The second test to evaluate endogeneity is the Hausman test (1978), in which the null hypothesis assumes no systematic difference in the coefficients estimated using ordinary least squares and twostage least squares. This is equivalent to saying that the variable under study is exogenous where $H_{0}$ is not rejected. The test is $\chi^{2}$ distributed with degrees of freedom equivalent to the number of potentially endogenous regressors.

Two methods can be used to assess the validity of the instruments used. The first is to observe the individual statistical significance and explanatory power of each instrument using Shea's partial $\mathrm{R}^{2}$ (1997). The second method is to use the Sargan test. The hypothesis is that good instruments must be closely correlated with the potentially endogenous variable and uncorrelated with the error terms (Wooldridge, 2002).

The Sargan test is used to check whether the chosen instruments are independent of the error terms. In this test, the null hypothesis is that the instruments are valid. The statistic is $\chi^{2}$ distributed with degrees of freedom equivalent to the number of overidentifying restrictions, that is to say, the number of instruments minus the number of regressors (Gujarati, 2004). As the test is not directly applicable to the two-stage probit model, a two-stage ordinary least squares model was estimated to obtain the statistic.

\section{III}

\section{Determinants of technological innovation in Argentina and Brazil}

This section examines two sets of econometric results. ${ }^{7}$ The first includes probit regressions with endogenous regressors for innovative products introduced by Argentina and Brazil. The aim of the second is to evaluate the determinants of process innovation.

\footnotetext{
${ }^{6}$ The STATA programme function for this model is IVPROBIT, with the option of maximum likelihood estimation.

${ }^{7}$ This section contains many references to the CNAE, Brazil's standard national classification of economic activities (Classificação Nacional de Atividades Econômicas), which was established for Brazil by the Brazilian Geographical and Statistical Institute (IBGE). Appendix B describes the relevant CNAE divisions. In this article, the Brazilian CNAE divisions have also been applied to Argentina.
}

\section{Product innovation}

This section presents the results for Argentina and Brazil of the regressions on the determinants of product innovation. The value of the probit model dependent variable is 'one' when the firm introduces innovative products into the domestic market and 'zero' in all other cases. Five variables were included to measure the relative importance of each type of innovation expenditure. Two variables of innovative effort were included: one to measure the proportion of a firm's personnel who are involved in research and development and the other to measure the intensity of its research and development activities. 
Control variables of firms' external trade integration (import and export coefficients) and performance and structural variables (productivity and market concentration rates) were introduced. To avoid problems of endogeneity, they refer to a period predating that indicated by firms as an innovation period. For the reasons discussed earlier, the import coefficient was considered as an endogenous regressor and was calculated using the instrumental-variables probit method. Structural dummy variables were also included to capture the influence of source of capital, company size and technological opportunities in sectors. ${ }^{8}$

Table 1 shows two regressions. The probit model includes estimates of coefficients, standard deviations and marginal effects without considering the possibility of endogeneity of the export coefficient. The problem is corrected in the instrumental-variables probit model. ${ }^{9}$

In general the instruments chosen to estimate the export coefficient were appropriate (dummy variable for exports in 1997 and GDP growth rate of countries of destination for firms' exports), as confirmed by the significance ( $p$-value) of each instrument (appendix C, table C.1). As tables C.1 and C. 2 also show, the Sargan test reveals that the instruments are uncorrelated with the error term of the equation in which innovation is the dependent variable, as the null hypothesis is not rejected and the Hausman and Wald tests indicate that the exogeneity hypothesis cannot be supported. Shea's partial $\mathrm{R}^{2}$ also indicates that the instruments help to explain the endogenous variable (13\% in the case of Brazil and 23\% in the case of Argentina).

A comparison of the regressions in table 1 shows that the coefficients of the regressors change very little and diminish only after applying the instrumentalvariables method, in addition to the change in sign and the increase in the export coefficient value. Even though the variable was constructed to include a time lag with respect to the innovation period in the probit regression, its sign is negative and its value is not significant, indicating a theoretically unexpected result that belies the facts. However, the problem is resolved by using the instrumental-variables probit regression.

\footnotetext{
${ }^{8}$ See phase one of the instrumental-variables probit regression in appendix C (tables C.1 to C.4).

${ }^{9}$ As different statistical programmes were used, the exact number of firms for the regressions of the two econometric exercises was not available. The SAS statistical analysis software programme was used for the conventional probit model and the STATA software programme was used for the instrumental-variables probit model.
}

The positive sign of the export coefficient in the second econometric exercise captures the stimulant effect of exports on innovation. An export-driven propensity to innovate, measured by the marginal probability, is the second most significant explanatory variable. Fransman (1985) advances four theoretical arguments to corroborate the result, all of which exist in international literature: (i) greater competitive pressure, which promotes better product quality and lower costs; (ii) more opportunities for international intercompany learning; (iii) expansion of the firm's market, which encourages firms to exploit economies of scale and increase the division of labour, and (iv) greater capacity for importing better inputs, which increases the economy's overall productivity.

In principle, imports also provide a means for acquiring more advanced technology incorporated into machinery and equipment or into finished products, which can even lead to what is known as "reverse engineering". ${ }^{10}$ However, the mere fact of importing products can increase competition and force national producers to improve their products and processes. The Republic of Korea is a good example in the area of capital goods imports. According to Viotti (2002), its policy for capital goods importation was accompanied by complementary strategies of technology absorption, learning and active incremental innovation (that is to say, adapting or perfecting technology).

Even though the results of table 1 show the positive effect of imports on the propensity to innovate, in the case of Brazil exports are three times more important than imports in terms of marginal probability. In the case of Argentina (table 2), the marginal effects of imports are similar to those of exports after using the instrumental-variables method to correct the estimates. According to the conventional probit method, firms' export coefficient is positive and significant. However, its value is underestimated by the endogeneity problem. Once the estimates are corrected using the instrumental-variables method, the export coefficient increases to 1.68 and the import coefficient decreases to 1.71 , producing similar marginal probabilities.

The stimulant effect of imports in Argentina and Brazil accords with the fairly heavy impact of capital goods imports on technology training in many of

\footnotetext{
${ }^{10}$ Reverse engineering is understood to mean a learning and innovation process based on analysing electronic devices, electrical components, computer programmes or machinery to find out how they work and to duplicate or enhance them.
} 
TABLE 1

Probit Regression of Product Innovation in Brazilian Industrial Firms, 2000a

\begin{tabular}{|c|c|c|c|c|c|c|}
\hline \multirow{2}{*}{ Explanatory variables } & \multicolumn{3}{|c|}{ Probit } & \multicolumn{3}{|c|}{ Instrumental-variables probit } \\
\hline & Coefficient & $\begin{array}{l}\text { Standard } \\
\text { deviation }\end{array}$ & $\begin{array}{c}\text { Marginal } \\
\text { probability }\end{array}$ & Coefficient & $\begin{array}{l}\text { Standard } \\
\text { deviation }\end{array}$ & $\begin{array}{c}\text { Marginal } \\
\text { probability }\end{array}$ \\
\hline Intercept & $-2.60 * * *$ & 0.06 & - & $-2.44 * * *$ & 0.05 & - \\
\hline Export coefficient & $-0.16^{\mathrm{NS}}$ & 0.14 & -0.02 & $1.65 * * *$ & 0.18 & 0.12 \\
\hline Import coefficient & $0.55 * * *$ & 0.22 & 0.06 & $0.52 * * *$ & 0.21 & 0.04 \\
\hline Productivity & $0.00 * * *$ & 0.00 & 0.00 & $0.00 * * *$ & 0.00 & 0.00 \\
\hline Concentration & $0.33^{* * *}$ & 0.06 & 0.04 & $0.29 * * *$ & 0.05 & 0.02 \\
\hline Personnel assigned to $R \& D$ & $0.03 * * *$ & 0.00 & 0.00 & $0.03 * * *$ & 0.00 & 0.00 \\
\hline Intensity of $R \& D$ activities & $0.12 * * *$ & 0.01 & 0.01 & $0.11 * * *$ & 0.01 & 0.01 \\
\hline Internal R\&D effort & $1.02 * * *$ & 0.07 & 0.11 & $0.96 * * *$ & 0.07 & 0.07 \\
\hline Purchase of R\&D & $4.05 * * *$ & 0.49 & 0.43 & $3.70 * * *$ & 0.48 & 0.27 \\
\hline Expenditure on external knowledge & $1.25 * * *$ & 0.31 & 0.13 & $1.05 * * *$ & 0.29 & 0.08 \\
\hline Expenditure on machinery & $0.70 * * *$ & 0.05 & 0.07 & $0.61 * * *$ & 0.04 & 0.05 \\
\hline Expenditure on industrial projects & $1.17 * * *$ & 0.14 & 0.12 & $1.06 * * *$ & 0.13 & 0.08 \\
\hline Dummy variable for source of capital & $0.38^{* * * *}$ & 0.06 & 0.04 & $0.22 * * *$ & 0.06 & 0.02 \\
\hline Dummy variable for medium-sized firms & $0.20 * * *$ & 0.04 & 0.02 & $0.11 * * *$ & 0.04 & 0.01 \\
\hline Dummy variable for large firms & $0.74 * * *$ & 0.07 & 0.08 & $0.55 * * *$ & 0.07 & 0.06 \\
\hline CNAE-16 & $0.30^{\mathrm{NS}}$ & 0.39 & 0.03 & $0.02^{\mathrm{NS}}$ & 0.35 & 0.00 \\
\hline CNAE-17 & $0.03^{\mathrm{NS}}$ & 0.09 & 0.00 & $0.02^{\mathrm{NS}}$ & 0.08 & 0.00 \\
\hline CNAE-18 & $-0.41 * * *$ & 0.11 & -0.04 & $-0.40 * * *$ & 0.10 & -0.02 \\
\hline CNAE-19 & $-0.10^{\mathrm{NS}}$ & 0.11 & -0.01 & $-0.26^{* * *}$ & 0.09 & -0.02 \\
\hline CNAE-20 & $-0.04^{\mathrm{NS}}$ & 0.12 & 0.00 & $-0.28 * * *$ & 0.11 & -0.02 \\
\hline CNAE-21 & $0.17^{\mathrm{NS}}$ & 0.11 & 0.02 & $0.22 * *$ & 0.10 & 0.02 \\
\hline CNAE-22 & $0.37 * * *$ & 0.09 & 0.04 & $0.39 * * *$ & 0.08 & 0.04 \\
\hline CNAE-23 & $-0.93 * *$ & 0.43 & -0.10 & $-0.85 * *$ & 0.42 & -0.03 \\
\hline CNAE-24 & $0.45^{* * *}$ & 0.07 & 0.05 & $0.45 * * *$ & 0.06 & 0.05 \\
\hline CNAE-25 & $0.21 * * *$ & 0.08 & 0.02 & $0.25 * * *$ & 0.07 & 0.02 \\
\hline CNAE-26 & $0.03^{\mathrm{NS}}$ & 0.09 & 0.00 & $0.04^{\mathrm{NS}}$ & 0.08 & 0.00 \\
\hline CNAE-27 & $0.24 * *$ & 0.12 & 0.03 & $0.16^{\mathrm{NS}}$ & 0.11 & 0.01 \\
\hline CNAE- 28 & $0.06^{\mathrm{NS}}$ & 0.08 & 0.01 & $0.08^{\mathrm{NS}}$ & 0.07 & 0.01 \\
\hline CNAE-29 & $0.75 * * *$ & 0.06 & 0.08 & $0.66 * * *$ & 0.05 & 0.08 \\
\hline CNAE-30 & $-0.13^{\mathrm{NS}}$ & 0.29 & -0.01 & - & - & - \\
\hline CNAE-31 & $0.48 * * *$ & 0.09 & 0.05 & $0.46^{* * *}$ & 0.08 & 0.05 \\
\hline CNAE-32 & $0.17^{\mathrm{NS}}$ & 0.13 & 0.02 & $0.19^{\mathrm{NS}}$ & 0.13 & 0.02 \\
\hline CNAE-33 & $0.08^{\mathrm{NS}}$ & 0.13 & 0.01 & $0.02^{\mathrm{NS}}$ & 0.12 & 0.00 \\
\hline CNAE-34 & $0.33^{* * * *}$ & 0.09 & 0.03 & $0.31 * * *$ & 0.08 & 0.03 \\
\hline CNAE-35 & $0.78^{* * *}$ & 0.16 & 0.08 & $0.75^{* * *}$ & 0.14 & 0.11 \\
\hline CNAE-36 & $0.02^{\mathrm{NS}}$ & 0.08 & 0.00 & - & - & - \\
\hline Log likelihood & \multicolumn{3}{|c|}{-3727.51} & \multicolumn{3}{|c|}{4004.98} \\
\hline Wald statistic ${ }^{\mathrm{b}}$ & \multicolumn{3}{|c|}{$2800.28 * * *$} & \multicolumn{3}{|c|}{$2786.45 * * *$} \\
\hline Number of observations & \multicolumn{3}{|c|}{6626} & \multicolumn{3}{|c|}{6710} \\
\hline
\end{tabular}

Source: author, on the basis of the SAS programme.

a $\quad R \& D=$ research and development. CNAE: Brazil's standard national classification of economic activities.

b Joint significance test of the explanatory variables ( $\chi 2$ distribution with 35 and 33 degrees of freedom respectively).

* Significant to $10 \%$. ** Significant to $5 \%$. *** Significant to $1 \%$. NS= not significant. 
TABLE 2

Probit Regression of Product Innovation in Argentinean Industrial Firms, 2001ª

\begin{tabular}{|c|c|c|c|c|c|c|}
\hline \multirow{2}{*}{ Explanatory variables } & \multicolumn{3}{|c|}{ Probit } & \multicolumn{3}{|c|}{ Instrumental-variables probit } \\
\hline & Coefficient & $\begin{array}{l}\text { Standard } \\
\text { deviation }\end{array}$ & $\begin{array}{c}\text { Marginal } \\
\text { probability }\end{array}$ & Coefficient & $\begin{array}{l}\text { Standard } \\
\text { deviation }\end{array}$ & $\begin{array}{c}\text { Marginal } \\
\text { probability }\end{array}$ \\
\hline Intercept & $-1.42 * * *$ & 0.05 & - & $-1.45^{* * *}$ & 0.04 & - \\
\hline Export coefficient & $0.51 * * *$ & 0.09 & 0.16 & $1.68 * * *$ & 0.16 & 0.41 \\
\hline Import coefficient & $2.14 * * *$ & 0.17 & 0.67 & $1.71 * * *$ & 0.17 & 0.42 \\
\hline Productivity & $0.00 * * *$ & 0.00 & 0.00 & $0.00 * * *$ & 0.00 & 0.00 \\
\hline Concentration & $0.05^{* *}$ & 0.03 & 0.02 & $0.04 *$ & 0.02 & 0.01 \\
\hline Personnel assigned to $R \& D$ & $0.05^{* * *}$ & 0.00 & 0.02 & $0.04 * * *$ & 0.00 & 0.01 \\
\hline Intensity of $R \& D$ activities & $0.26^{* * *}$ & 0.04 & 0.08 & $0.25^{* * *}$ & 0.04 & 0.06 \\
\hline Internal R\&D effort & $0.73^{* * *}$ & 0.10 & 0.23 & $0.77 * * *$ & 0.10 & 0.19 \\
\hline Purchase of R\&D & $1.67 * * *$ & 0.39 & 0.52 & $1.79 * * *$ & 0.38 & 0.44 \\
\hline Expenditure on external knowledge & $2.63 * * *$ & 0.86 & 0.82 & $2.22 * * *$ & 0.83 & 0.55 \\
\hline Expenditure on machinery & $0.73 * * *$ & 0.04 & 0.23 & $0.72 * * *$ & 0.04 & 0.18 \\
\hline Expenditure on industrial projects & $2.18 * * *$ & 0.17 & 0.68 & $2.07 * * *$ & 0.16 & 0.51 \\
\hline Dummy variable for source of capital & $-0.36 * * *$ & 0.07 & -0.11 & $-0.41 * * *$ & 0.07 & -0.08 \\
\hline Dummy variable for medium-sized firms & $0.22 * * *$ & 0.05 & 0.07 & $0.14 * * *$ & 0.05 & 0.04 \\
\hline Dummy variable for large firms & $0.37 * * *$ & 0.15 & 0.12 & $0.32 * *$ & 0.14 & 0.09 \\
\hline CNAE-16 & $-0.28^{\mathrm{NS}}$ & 0.81 & -0.09 & $-1.01^{\mathrm{NS}}$ & 0.72 & -0.14 \\
\hline CNAE-17 & $0.11^{\mathrm{NS}}$ & 0.07 & 0.03 & $0.14^{* *}$ & 0.06 & 0.04 \\
\hline CNAE- 18 & $-0.03^{\mathrm{NS}}$ & 0.09 & -0.01 & $0.10^{\mathrm{NS}}$ & 0.08 & 0.02 \\
\hline CNAE-19 & $0.04^{\mathrm{NS}}$ & 0.08 & 0.01 & $-0.16^{* *}$ & 0.08 & -0.04 \\
\hline CNAE-20 & $-1.32 * * *$ & 0.21 & -0.41 & $-1.18 * * *$ & 0.21 & -0.16 \\
\hline CNAE-21 & $-0.10^{\mathrm{NS}}$ & 0.11 & -0.03 & $-0.05^{\mathrm{NS}}$ & 0.11 & -0.01 \\
\hline CNAE-22 & $0.19^{* *}$ & 0.08 & 0.06 & $0.28 * * *$ & 0.07 & 0.08 \\
\hline CNAE-23 & $0.44^{\mathrm{NS}}$ & 0.56 & 0.14 & $0.25^{\mathrm{NS}}$ & 0.55 & 0.07 \\
\hline CNAE-24 & $0.12^{*}$ & 0.07 & 0.04 & $0.18^{* * *}$ & 0.06 & 0.05 \\
\hline CNAE-25 & $0.12^{*}$ & 0.07 & 0.04 & $0.03^{\mathrm{NS}}$ & 0.07 & 0.01 \\
\hline CNAE-26 & $0.59 * * *$ & 0.10 & 0.18 & $0.67 * * *$ & 0.09 & 0.21 \\
\hline CNAE-27 & $-0.15^{\mathrm{NS}}$ & 0.11 & -0.05 & $-0.10^{\mathrm{NS}}$ & 0.11 & -0.02 \\
\hline CNAE-28 & $-0.36^{* * *}$ & 0.08 & -0.11 & $-0.31 * * *$ & 0.07 & -0.07 \\
\hline CNAE-29 & $0.54 * * *$ & 0.09 & 0.17 & $0.54 * * *$ & 0.08 & 0.16 \\
\hline CNAE-30 & - & - & - & - & - & - \\
\hline CNAE-31 & $-0.68 * * *$ & 0.12 & -0.21 & $-0.61 * * *$ & 0.11 & -0.11 \\
\hline CNAE-32 & $-0.80^{\mathrm{NS}}$ & 0.58 & -0.25 & $-0.14^{\mathrm{NS}}$ & 0.42 & -0.03 \\
\hline CNAE-33 & $-0.19^{\mathrm{NS}}$ & 0.19 & -0.06 & $-0.12^{\mathrm{NS}}$ & 0.18 & -0.03 \\
\hline CNAE-34 & $0.17 * *$ & 0.09 & 0.05 & $0.06^{\mathrm{NS}}$ & 0.08 & 0.01 \\
\hline CNAE-35 & $0.53 * * *$ & 0.15 & 0.16 & $0.52 * * *$ & 0.14 & 0.16 \\
\hline CNAE-36 & $-0.17^{\mathrm{NS}}$ & 0.10 & -0.05 & - & - & - \\
\hline Log likelihood & \multicolumn{3}{|c|}{-3753.30} & \multicolumn{3}{|c|}{342.77} \\
\hline Wald statistic ${ }^{b}$ & \multicolumn{3}{|c|}{$1726.45 * * *$} & \multicolumn{3}{|c|}{$1924.95 * * *$} \\
\hline Number of observations & \multicolumn{3}{|c|}{1256} & \multicolumn{3}{|c|}{1286} \\
\hline
\end{tabular}

$\mathrm{R}^{2}=0.82 \quad$ Probability of correct prediction: $74.9 \%$

Source: author, on the basis of the SAS programme.

a $\quad R \& D=$ research and development. CNAE $=$ Brazil's standard national classification of economic activities.

b Joint significance test of the explanatory variables ( $\chi^{2}$ distribution with 34 and 33 degrees of freedom respectively).

* Significant to $10 \%$. ** Significant to $5 \%$. *** Significant to $1 \%$. NS= not significant. 
the firms in both countries. Moreover, the significant stimulant effect of exports on Brazilian firms' product innovation appears to denote a measure of success in diversifying Brazil's export pattern, gearing it towards technologically more complex products that are more in line with Fransman's abovementioned four positive effects of exports on innovation (Fransman, 1985).

In Brazil, the purchase of R\&D is by far the most important factor in boosting product innovation, which reveals the technological dependence of Brazilian industrial firms. The data in table 1 also show that expenditure on innovation is not substitutive but complementary. In terms of marginal probability, spending on machinery and equipment has the least impact on product innovation.

In short, the results highlight four characteristics of Brazil's industrial firms with respect to their capacity to introduce new products into the domestic market: (i) the importance of external acquisition of technology by means of purchasing $R \& D$, licences, acquisition of know-how, patents, registered trademarks, consulting services and technology transfer agreements; (ii) their weak internal research and development capacity, given that third-party service provision in this area (measured in terms of marginal probability) is four times greater than firms' internal research and development effort; (iii) the relatively small contribution of machinery and equipment acquisition to product innovation, and (iv) the prominent role of exports as an innovation driver.

In Argentina, these four characteristics are also very pronounced, although there are a few differences (table 2). First and foremost, the order of importance of the two main types of innovation expenditure is not the same. In Argentina, expenditure on other external knowledge and on industrial projects contributes most to the likelihood of product innovation, whereas the purchase of R\&D comes second. This may mean that the acquisition of more definitive forms of technological knowledge (such as licences, purchase of technical know-how, patents and registered trademarks) is more useful to Argentine firms than the purchase of inputs for innovation in the form of R\&D, which appears to predominate in Brazilian firms. A second difference between the two countries is the contribution made by external trade-integration variables to product innovation by firms. Whereas exports are clearly the predominant factor in Brazil, in Argentina exports and imports make a similar contribution.

Just as in Brazil, machinery and equipment expenditure in Argentina is the least important type of expenditure for new product creation. The data also suggest that internal research and development capacity is poor in both economies and only serves to complement the external acquisition of knowledge for use in product innovation.

According to the information for both countries, structural and performance variables make a relatively small contribution to firms' propensity for product innovation. In other words, when the significant variables of innovative effort and external trade integration are not omitted but, on the contrary, are clearly explained or specified in the model, the importance of the traditional structure and performance factors diminishes. This means that, irrespective of firms' market power (concentration), size, origin and performance (productivity), the factors that determine the propensity of Argentine and Brazilian firms to engage in product innovation are all types of innovative effort and external trade integration, especially exports.

Even so, structural factors are still significant. Observations show that the larger a firm is, the greater its propensity to innovate. The approximate marginal probability of large firms in Argentina and Brazil is 9\% and $6 \%$ respectively, whereas in medium-sized firms it is $4 \%$ and $1 \%$ respectively. These results confirm one of Schumpeter's two hypotheses (1961), according to which innovation would increase more than proportional to size of the firm. The other hypothesis is confirmed by the positive contribution of the concentration variable, whose effect on increasing the likelihood of innovation is positive and significant in both countries.

As the absolute size of firms is already considered in another variable, this result indicates that larger relative size (greater market power) favours innovation in both countries. In other words, company size is the determinant of innovation. If the sign were negative, it would indicate that emerging firms favour innovation. In this case, the incentive for innovation would be the determinant. The results for both countries' industrial firms are as expected, given that in intracompany innovation, the stock of knowledge (gained by imitation, incremental innovation and adaptation by purchasing technology) predominates over knowledge flow. It is possible for the sign to be negative in more industrialized economies, if the incentive for innovation (1934 theory of the young Schumpeter) predominates over innovative capacity (1942 theory of the mature Schumpeter).

The inverse causality relationship (the effect of innovation on concentration) is also consistent with the Schumpeterian vision, but only after a prolonged 
period of time. A technological breakthrough would be the starting point for a firm to grow and would enable it to take a market lead.

Productivity, which is a traditional measure of firms' performance and indicates their production efficiency, directly affects profitability, which is the key performance variable. It was included to test the relationship between performance (measured by productivity) and innovative effort (the extent to which firm's efficiency induces and boosts innovative effort). However, evidence indicates that productivity has no significant effect on the likelihood of innovation, even though its coefficient is statistically significant. ${ }^{11}$

The aim of the dummy variable for the source of capital is to capture differences in innovative effort between multinational companies and domestic firms. It was introduced because in specialized literature there are divergent views concerning the effect of multinational companies on national innovative capacity (Mansfield, 1974). An important difference between the two countries analyzed is the impact of the source of capital on the likelihood to innovate.

In Brazil, the presence of multinational companies increases the likelihood of innovation by approximately $2 \%$. The chosen category of reference and comparison is domestically-sourced capital. This is because foreign capital is believed to have a major influence on national innovative capacity. However, its importance needs to be evaluated by considering which types of effort multinational companies have made and whether their greater visibility in the area of innovation can be attributed to much more systematic activities in this area.

It is useful to make a comparison with Araújo's theory (2005), which reveals that the presence of multinational companies reduces the likelihood of domestic firms investing in research and development. Both results allow us to conclude that multinational companies make a limited contribution to national technological development because, even though they allow international technology transfer, they fail to develop the country's innovative capacity by creating local externalities (something that would be achieved if research and development activities were conducted locally).

\footnotetext{
${ }^{11}$ As with the concentration variable, the relationship between innovation and productivity may be characterized by dual causality. However, as mentioned in section two on methodology, the productivity variable relates to the year 1998. The objective is therefore to determine the influence of firms' past productivity on their current innovation performance.
}

As in the case of Brazil, multinational companies have no decisive impact on product innovation in Argentina either. On the contrary, their presence reduces the likelihood of innovation by around $8 \%$. Mansfield's classic hypothesis (1974) that multinationals would contribute to national technological development as vehicles for disseminating international technological best practice, does not appear to be true for Argentine industry. This is consistent with Chudnovsky's finding (1999) that the subsidiaries of multinationals in Argentina created few technological externalities, owing to the small scale of their innovative activities and their limited technology links with local suppliers and research centres. Chudnovsky, López and Pupato (2006) also corroborate this result, having found no significant relationship between foreign capital ownership and the propensity of firms to engage in innovative activities or launch innovations onto the market.

Following Pavitt's line of argument (1984), firms' propensity to innovate differs according to the sector to which they belong, as some sectors have more technological opportunities than others. Technological opportunities include the set of possibilities for technological advance (Klevorick, Levin et al, 1995). The chosen reference category for this study was the dummy variable for the manufacture of food products and beverages, as this is a wide-ranging sector of great importance to both countries' economies. According to Scherer (1965), technological opportunity is the factor that most influences inter-industrial differences when innovation results are measured using patent data, for instance.

In Brazil, the dummy sectoral variables that most contribute to the propensity to innovate correspond to the following CNAE divisions: pulp and paper (CNAE21), publishing and printing (CNAE-22), chemical products (CNAE-24), rubber and plastic products (CNAE25), machinery and equipment (CNAE-29), electrical machinery and apparatus (CNAE-31), vehicle assembly (CNAE-34) and other transport equipment (CNAE-35). In the following sectors, there is a lower likelihood of innovation compared with the reference category: manufacture of wearing apparel and accessories (CNAE18), leather and footwear (CNAE-19), wood products (CNAE-20) and coke and refined petroleum products (CNAE-23). The other seven dummy sectoral variables lack statistical significance in the regression and two were excluded from the programme as they were vectors comprising solely 0 or 1 .

The sectors under study exhibit heterogeneous indicators of technology content and patterns of 
technology effort, as well as diverging widely from Pavitt's taxonomy, which was originally formulated for developed countries. They include "supplierdominated" sectors, which are not the sectors that tend to have the greatest technological opportunities in developed countries (CNAE 21 and 22) and sectors classified by the Organisation for Economic Cooperation and Development as low technology (CNAE 22), medium-low technology (CNAE 25) and mediumhigh technology (CNAE-34).

This sectoral heterogeneity in Brazil's innovative capacity reflects not only the source of capital but also an industrial structure biased in favour of natural resource-based sectors, which sustain the export model. Given that such sectors tend to be supplier-dominated or exploit economies of scale, they entail little private research and development for the purposes of product innovation, since technology effort is concentrated on acquiring machinery and equipment and improving production inputs and processes. Moreover, in national knowledge-based sectors, which rely on specialist suppliers and make intensive use of information, the research and development effort is limited because absorption is a passive process that is dependent on international technology-transfer mechanisms.

Sectoral heterogeneity also reflects the fragile industrialization process in Latin American economies, which is incomplete and has created gaps in their technology matrices. The result is that, even where input-product matrices are "complete", as in Brazil's industrial structure, some sectors are under-represented, especially in the capital goods segments, and this weakens national capacity to create new products and processes. The very concept of innovation means different things in different countries of the region, as our study's dependent variable is itself linked with innovations targeted at the domestic market rather than the international market, in stark contrast to those of technologically advanced countries.

These same observations are also true for Argentina's industry, although there are some sectoral differences compared with Brazil. The significant dummy sectoral variables in the regression in table 2 were as follows: textile products (CNAE-17), publishing and printing (CNAE-22), chemical products (CNAE-24), non-metallic mineral products (CNAE26), machinery and equipment (CNAE-29) and other transport equipment (CNAE-35).

Another group of sectors exhibits a negative coefficient in the regression, meaning that it does not stand out from food products and beverages. Some such sectors are: leather and footwear (CNAE-19), wood products (CNAE-20), fabricated metal products (CNAE-28) and electrical machinery and apparatus (CNAE-31). A marked difference with respect to Brazil is the inclusion of CNAE-31 in this group, showing the weak innovative capacity of this sector in Argentina. The nine other dummy sectoral variables have no statistical significance in the regression and two were excluded from the programme as they were vectors comprising solely 0 or 1 .

\section{Process innovation}

Below are the results of the regression to estimate the propensity of Brazilian and Argentine firms for process innovation, showing major differences compared with product innovation.

The instruments chosen to estimate the export coefficient are significant in the case of Brazil because they have major individual significance ( $p$ value) and pass the Sargan test. The Hausman and Wald tests indicate that the exogeneity hypothesis cannot be supported (appendix C, table C.3). In the case of Argentina, perhaps because less prolific data was available for use as instruments, the Sargan test rejects the null hypothesis of orthogonal error significant to $5 \%$, calling into question the validity of the instruments (appendix C, table C.4). However, one of the instruments chosen (a dummy variable) has individual statistical significance in the regression, while the same is not true of the GDP growth of export destination countries.

As regards the type of expenditure associated with Brazilian process innovation (table 3 ), the magnitude of marginal probability reveals that the chief determinant of innovation is the purchase of R\&D, as it is in the case of product innovation. The order of importance of product innovation determinants differs only in terms of the role played by the 'internal research and development effort', which, in the case of process innovation, has the least impact on the likelihood of innovation. This was to be expected, given the heavy involvement of machinery suppliers and technology service providers in innovations that reduce production costs. In such a case, the complementary nature of this expenditure is likely to be even more marked than in product innovation. Amazingly the marginal probability of expenditure on machinery and equipment is fairly low.

Of all expenditure on innovation, only the internal research and development effort contributes less to the propensity to innovate. Even though these various 
TABLE 3

Brazil: determinants of the likelihood of process innovation, $2000^{\text {a }}$

\begin{tabular}{|c|c|c|c|c|c|c|}
\hline \multirow{2}{*}{ Explanatory variables } & \multicolumn{3}{|c|}{ Probit } & \multicolumn{3}{|c|}{ Instrumental-variables probit } \\
\hline & Coefficient & $\begin{array}{l}\text { Standard } \\
\text { deviation }\end{array}$ & $\begin{array}{c}\text { Marginal } \\
\text { probability }\end{array}$ & Coefficient & $\begin{array}{l}\text { Standard } \\
\text { deviation }\end{array}$ & $\begin{array}{c}\text { Marginal } \\
\text { probability }\end{array}$ \\
\hline Intercept & $-2.69 * * *$ & 0.06 & - & $-2.71 * * *$ & 0.06 & - \\
\hline Export coefficient & $0.41 * * *$ & 0.13 & 0.03 & $1.19 * * *$ & 0.22 & 0.04 \\
\hline Import coefficient & $2.12 * * *$ & 0.23 & 0.15 & $2.03 * * *$ & 0.23 & 0.07 \\
\hline Productivity & $0.00^{\mathrm{NS}}$ & 0.00 & 0.00 & $0.00 *$ & 0.00 & 0.00 \\
\hline Concentration & $0.25 * * *$ & 0.05 & 0.02 & $0.20 * * *$ & 0.05 & 0.01 \\
\hline Personnel assigned to $R \& D$ & $0.03 * * *$ & 0.00 & 0.00 & $0.03 * * *$ & 0.00 & 0.00 \\
\hline $\mathrm{R} \& \mathrm{D}$ intensity & $0.08 * * *$ & 0.01 & 0.01 & $0.08 * * *$ & 0.01 & 0.00 \\
\hline Internal R\&D effort & $0.69 * * *$ & 0.09 & 0.05 & $0.69 * * *$ & 0.08 & 0.02 \\
\hline Purchase of R\&D & $2.26 * * *$ & 0.48 & 0.16 & $2.34 * * *$ & 0.48 & 0.08 \\
\hline Expenditure on external knowledge & $1.49 * * *$ & 0.33 & 0.11 & $1.32 * * *$ & 0.32 & 0.05 \\
\hline Expenditure on machinery & $1.07 * * *$ & 0.05 & 0.08 & $1.04 * * *$ & 0.05 & 0.04 \\
\hline Expenditure on industrial projects & $1.17 * * *$ & 0.16 & 0.08 & $1.15^{* * *}$ & 0.15 & 0.04 \\
\hline Dummy variable for source of capital & $0.14^{* *}$ & 0.07 & 0.01 & $0.10^{\mathrm{NS}}$ & 0.07 & 0.00 \\
\hline Dummy variable for medium-sized firms & $0.45^{* * *}$ & 0.04 & 0.03 & $0.41 * * *$ & 0.04 & 0.02 \\
\hline Dummy variable for large firms & $1.02 * * *$ & 0.07 & 0.07 & $0.97 * * *$ & 0.07 & 0.09 \\
\hline CNAE-16 & $-1.50 * *$ & 0.72 & -0.11 & $-1.28 *$ & 0.69 & -0.01 \\
\hline CNAE-17 & $-0.04^{\mathrm{NS}}$ & 0.09 & 0.00 & $0.01^{\mathrm{NS}}$ & 0.08 & 0.00 \\
\hline CNAE-18 & $-0.97 * * *$ & 0.15 & -0.07 & $-0.91 * * *$ & 0.15 & -0.02 \\
\hline CNAE-19 & $-0.17^{*}$ & 0.10 & -0.01 & $-0.21 * *$ & 0.10 & -0.01 \\
\hline CNAE-20 & $-0.28 * *$ & 0.13 & -0.02 & $-0.35 * * *$ & 0.12 & -0.01 \\
\hline CNAE-21 & $0.03^{\mathrm{NS}}$ & 0.11 & 0.00 & $0.11^{\mathrm{NS}}$ & 0.11 & 0.00 \\
\hline CNAE-22 & $0.24 * * *$ & 0.10 & 0.00 & $0.32 * * *$ & 0.09 & 0.02 \\
\hline CNAE-23 & $-1.07 * *$ & 0.45 & -0.08 & $-0.98 * *$ & 0.45 & -0.01 \\
\hline CNAE-24 & $0.07^{\mathrm{NS}}$ & 0.08 & 0.01 & $0.15^{* *}$ & 0.07 & 0.01 \\
\hline CNAE-25 & $-0.05^{\mathrm{NS}}$ & 0.08 & 0.00 & $0.02^{\mathrm{NS}}$ & 0.08 & 0.00 \\
\hline CNAE-26 & $0.13^{\mathrm{NS}}$ & 0.09 & 0.01 & $0.17 * *$ & 0.08 & 0.01 \\
\hline CNAE-27 & $-0.05^{\mathrm{NS}}$ & 0.14 & 0.00 & $-0.04^{\mathrm{NS}}$ & 0.14 & 0.00 \\
\hline CNAE-28 & $-0.04^{\mathrm{NS}}$ & 0.08 & 0.00 & $0.03^{\mathrm{NS}}$ & 0.08 & 0.00 \\
\hline CNAE-29 & $-0.19 * *$ & 0.08 & -0.01 & $-0.15^{* *}$ & 0.07 & 0.00 \\
\hline CNAE-30 & $-1.42 * * *$ & 0.56 & -0.11 & - & - & - \\
\hline CNAE-31 & $0.09^{\mathrm{NS}}$ & 0.10 & 0.01 & $0.16^{*}$ & 0.10 & 0.01 \\
\hline CNAE-32 & $0.17^{\mathrm{NS}}$ & 0.14 & 0.01 & $0.26^{*}$ & 0.13 & 0.01 \\
\hline CNAE-33 & $-0.66 * * *$ & 0.18 & -0.05 & $-0.59 * * *$ & 0.18 & -0.01 \\
\hline CNAE-34 & $-0.03^{\mathrm{NS}}$ & 0.10 & 0.00 & $0.01^{\mathrm{NS}}$ & 0.09 & 0.00 \\
\hline CNAE-35 & $-0.83 * * *$ & 0.34 & -0.06 & $-0.72 * *$ & 0.33 & -0.01 \\
\hline CNAE-36 & $-0.14 *$ & 0.08 & -0.01 & - & - & - \\
\hline Log likelihood & \multicolumn{3}{|c|}{-2862.52} & \multicolumn{3}{|c|}{4791.04} \\
\hline Wald statistic ${ }^{\mathrm{b}}$ & \multicolumn{3}{|c|}{$1741.28 * * *$} & \multicolumn{3}{|c|}{$1828.50 * * *$} \\
\hline Number of observations & \multicolumn{3}{|c|}{6626} & \multicolumn{3}{|c|}{6710} \\
\hline
\end{tabular}

$\mathrm{R}^{2}=0.33 \quad$ Probability of correct prediction: $86.9 \%$

Source: author, on the basis of the SAS programme.

a $\quad \mathrm{R} \& \mathrm{D}=$ research and development. CNAE $=$ Brazil's standard national classification of economic activities.

b Joint significance test of the explanatory variables ( $\chi^{2}$ distribution with 35 and 33 degrees of freedom respectively).

* Significant to $10 \%$. ** Significant to $5 \%$. *** Significant to $1 \%$. NS= not significant. 
types of expenditure form a fairly complementary whole, the role they play reveals the importance of each type of expenditure in the innovation process. In Brazil, the pattern of process innovation during the import substitution period relied chiefly on the purchase of machinery, especially imported machinery (Tavares, 2000).

Judging by data for the recent period subsequent to trade opening and monetary stabilization, the pattern of process innovation has shifted more towards the purchase of disembodied knowledge. This suggests progress compared with the previous period, when technological transfers were only based on embodied capital-goods purchases.

This new process innovation model also appears to be developing in Argentina, albeit with less intensity. Table 4 shows that expenditure on the purchase of R\&D, industrial projects and machinery and equipment, in that order, are the main factors of process innovation, whereas internal research and development activities come second. The difference is that expenditure on other external knowledge has an adverse effect on process innovation. In spite of this unexpected negative result, which could be caused by errors in the primary research data, expenditure on other external knowledge in Brazil is still the second most important expenditure influencing the propensity for process innovation.

The other two variables that also measure firms' innovative effort are the proportion of their personnel assigned to research and development activities and the intensity of research and development activities (expenditure/turnover ratio). The variable for R\&D personnel has a positive sign and is significant, although it is not very important in either of the two countries, just as in the case of product innovation. With respect to the intensity of research and development activities, the differences between Brazilian and Argentine firms that have introduced process innovations are much the same as for product innovation. In other words, the intensity of research and development activities increases the likelihood of innovation more in Argentine firms than in Brazilian firms. As they are generic indicators of innovative effort, these variables are less significant for the two countries than variables related with the type of expenditure.

As regards external trade integration, both exports and imports can be seen to heavily influence the propensity for process innovation in both countries. However, the increase in the likelihood of innovation arising from external trade integration is much greater in Argentina than in Brazil, and is much more akin to the product innovation pattern, even though Argentina's export coefficient is not statistically significant. Whereas in Argentina the impact of imports on the propensity for process innovation is much greater than the joint impact of expenditure on innovation activities, in Brazil these effects are as important as those of trade integration.

This could reflect differences in the degree of trade openness (measured by adding the export and import coefficients), which, in structural terms, is determined by the size of the two economies. The Argentine economy's greater trade openness is therefore expected to boost the positive effects of its trade integration in promoting innovation, especially in processes, which tend to be tangible and exist in the international technology market. Moreover, technological externalities are expected to be greater in the Brazilian economy, as its industrial scale increases the propensity of established firms to innovate by making the results of innovative effort more profitable and effective.

Finally, the structure and performance variables for process innovation tend to be less important than the variables for innovative effort, as was seen in the case of product innovation. With regard to concentration, the results confirm that in Brazil it contributes to process innovation (table 3 ), although firms' likelihood of process innovation is lower than that of product innovation (see table 1 above). Schumpeter's "mature" economic theory is not borne out in Argentina, at least with respect to this variable, as its coefficient is not significant for process innovation (table 4 ). Moreover, productivity has virtually no influence on the decision of firms to introduce process innovations, which is much the same result as for firms engaging in product innovation.

In Brazil, although the source of capital has a positive sign, it is not an important factor of process innovation. In Argentina, the source of capital dummy variable has a negative sign and is significant in process innovation, as it is in product innovation. This confirms the results obtained by Chudnovsky (1999) and Chudnovsky, López and Pupato (2006).

As in previous cases, the dummy variables for evaluating the relative importance of company size also show that the propensity to innovate is greater in large firms. The marginal probability is $9 \%$ in Brazil and 14\% in Argentina, which are higher values than for product innovation in both countries. This means not only that company size is important for both types of innovation in the two countries, but that its importance 
TABLE 4

Probit Regression of Process Innovation in Argentinean Industrial Firms, 2001

\begin{tabular}{|c|c|c|c|c|c|c|}
\hline \multirow{2}{*}{ Explanatory variables } & \multicolumn{3}{|c|}{ Probit } & \multicolumn{3}{|c|}{ Instrumental-variables probit } \\
\hline & Coefficient & $\begin{array}{l}\text { Standard } \\
\text { deviation }\end{array}$ & $\begin{array}{c}\text { Marginal } \\
\text { probability }\end{array}$ & Coefficient & $\begin{array}{l}\text { Standard } \\
\text { deviation }\end{array}$ & $\begin{array}{l}\text { Marginal } \\
\text { probability }\end{array}$ \\
\hline Intercept & $-1.92 * * *$ & 0.06 & - & $-2.05 * * *$ & 0.05 & - \\
\hline Export coefficient & $-0.03^{\mathrm{NS}}$ & 0.12 & 0.00 & $2.09 * * *$ & 0.19 & 0.24 \\
\hline Import coefficient & $1.98 * * *$ & 0.19 & 0.30 & $1.30 * * *$ & 0.20 & 0.15 \\
\hline Productivity & $0.00 * * *$ & 0.00 & 0.00 & $0.00^{*}$ & 0.00 & 0.00 \\
\hline Concentration & $0.03^{\mathrm{NS}}$ & 0.03 & 0.49 & $0.00^{\mathrm{NS}}$ & 0.03 & 0.00 \\
\hline Personnel assigned to R\&D & $0.05^{* * *}$ & 0.00 & 0.01 & $0.05^{* * *}$ & 0.00 & 0.01 \\
\hline Intensity of $\mathrm{R} \& \mathrm{D}$ activities & $0.22 * * *$ & 0.03 & 0.03 & $0.20 * * *$ & 0.03 & 0.02 \\
\hline Internal R\&D effort & $0.17 * * *$ & 0.12 & 0.03 & $0.30^{*}$ & 0.11 & 0.03 \\
\hline Purchase of R\&D & $1.11^{* *}$ & 0.49 & 0.17 & $1.11^{* *}$ & 0.50 & 0.13 \\
\hline Expenditure on external knowledge & $-0.34 * * *$ & 0.87 & -0.05 & $-0.47 * * *$ & 0.82 & -0.05 \\
\hline Expenditure on machinery & $0.71 * * *$ & 0.05 & 0.11 & $0.67 * * *$ & 0.05 & 0.08 \\
\hline Expenditure on industrial projects & $1.14 * * *$ & 0.19 & 0.17 & $0.95^{* * *}$ & 0.18 & 0.11 \\
\hline Dummy variable for source of capital & $-0.07^{\mathrm{NS}}$ & 0.08 & -0.01 & $-0.14^{*}$ & 0.08 & -0.01 \\
\hline Dummy variable for medium-sized firms & $0.23^{* * *}$ & 0.06 & 0.04 & $0.16^{* *}$ & 0.05 & 0.02 \\
\hline Dummy variable for large firms & $0.74 * * *$ & 0.16 & 0.11 & $0.74 * * *$ & 0.15 & 0.14 \\
\hline CNAE-16 & $-5.33^{\mathrm{NS}}$ & 3.62 & -0.82 & - & - & - \\
\hline CNAE-17 & $0.24 * * *$ & 0.08 & 0.04 & $0.37 * * *$ & 0.08 & 0.05 \\
\hline CNAE-18 & $-1.76^{* * *}$ & 0.36 & -0.27 & $-1.29 * * *$ & 0.33 & -0.06 \\
\hline CNAE-19 & $-0.18^{\mathrm{NS}}$ & 0.11 & -0.03 & $-0.41 * * *$ & 0.11 & -0.03 \\
\hline CNAE-20 & $-0.05^{\mathrm{NS}}$ & 0.13 & -0.01 & $0.22 *$ & 0.12 & 0.03 \\
\hline CNAE-21 & $0.25^{* *}$ & 0.12 & 0.04 & $0.42 * * *$ & 0.11 & 0.06 \\
\hline CNAE-22 & $-0.02^{\mathrm{NS}}$ & 0.10 & 0.00 & $0.22 * *$ & 0.10 & 0.03 \\
\hline CNAE-23 & $0.74^{\mathrm{NS}}$ & 0.58 & 0.11 & $0.43^{\mathrm{NS}}$ & 0.55 & 0.07 \\
\hline CNAE-24 & $-0.47 * * *$ & 0.09 & -0.07 & $-0.31 * * *$ & 0.09 & -0.03 \\
\hline CNAE-25 & $-0.02^{\mathrm{NS}}$ & 0.09 & 0.00 & $-0.10^{\mathrm{NS}}$ & 0.09 & -0.01 \\
\hline CNAE-26 & $0.58 * * *$ & 0.11 & 0.09 & $0.77 * * *$ & 0.11 & 0.15 \\
\hline CNAE-27 & $-0.44 * * *$ & 0.15 & -0.07 & $-0.25 *$ & 0.14 & -0.02 \\
\hline CNAE-28 & $-0.09^{\mathrm{NS}}$ & 0.09 & -0.01 & $0.07^{\mathrm{NS}}$ & 0.09 & 0.01 \\
\hline CNAE-29 & $0.32 * * *$ & 0.10 & 0.05 & $0.37 * * *$ & 0.09 & 0.05 \\
\hline CNAE-30 & - & - & - & - & - & - \\
\hline CNAE-31 & $-0.14^{\mathrm{NS}}$ & 0.13 & -0.02 & $0.06^{\mathrm{NS}}$ & 0.12 & 0.01 \\
\hline CNAE-32 & $-0.21^{\mathrm{NS}}$ & 0.56 & -0.03 & $0.15^{\mathrm{NS}}$ & 0.47 & 0.02 \\
\hline CNAE-33 & $0.26^{\mathrm{NS}}$ & 0.19 & 0.04 & $0.47 * * *$ & 0.18 & 0.08 \\
\hline CNAE-34 & $0.29 * * *$ & 0.10 & 0.05 & $0.22 * *$ & 0.10 & 0.03 \\
\hline CNAE-35 & $-0.23^{\mathrm{NS}}$ & 0.24 & -0.04 & $-0.07^{\mathrm{NS}}$ & 0.23 & -0.01 \\
\hline CNAE-36 & $-0.63 * * *$ & 0.17 & -0.10 & - & - & - \\
\hline Log likelihood & \multicolumn{3}{|c|}{-2206.45} & \multicolumn{3}{|c|}{1920.81} \\
\hline Wald statistic ${ }^{\mathrm{b}}$ & \multicolumn{3}{|c|}{$925.09 * * *$} & \multicolumn{3}{|c|}{$1100.10^{* * *}$} \\
\hline Number of observations & \multicolumn{3}{|c|}{1256} & \multicolumn{3}{|c|}{1282} \\
\hline
\end{tabular}

$\mathrm{R}^{2}=0.59 \quad$ Probability of correct prediction: $75.3 \%$

Source: author, on the basis of the SAS programme.

a $\quad R \& D=$ research and development. CNAE $=$ Brazil's standard national classification of economic activities.

b Joint significance test of the explanatory variables ( $\chi^{2}$ distribution with 34 and 32 degrees of freedom respectively).

* Significant to $10 \%$. ** Significant to $5 \%$. *** Significant to $1 \%$. NS= not significant. 
is greater in the case of process innovations, most of which are capital-intensive.

In Brazil, the dummy sectoral variables are significant and have a positive effect on promoting innovations in the following sectors: publishing and printing (CNAE-22), chemical products (CNAE-24), non-metallic mineral products (CNAE-26), electrical machinery and apparatus (CNAE-31) and electronic and communication equipment and apparatus (CNAE-32). In contrast, the following sectors do not stand out from the food products and beverages sector: tobacco products (CNAE-16), wearing apparel and accessories (CNAE18), leather and footwear (CNAE-19), wood products (CNAE-20), coke and refined petroleum products (CNAE-23), machinery and equipment (CNAE-29), medical, precision and optical instruments (CNAE-33) and other transport equipment (CNAE-35).

In Argentina, the sectors with the highest likelihood of process innovation are: textile products (CNAE-17),

\section{IV}

\section{Conclusions}

This article analysed the relative importance of the factors that have determined innovation in Brazilian and Argentine industrial firms, taking into account the two countries' distinctive characteristics in terms of technological change, including the high proportion of the innovative expenditures they spend on acquiring external knowledge and absorbing technology embodied into machinery and equipment, compared with their spending on internal research and development activities. Among the determinants of innovation, the article also considered a number of structural and performance characteristics of firms, such external trade integration, productivity, degree of market concentration, sectoral propensities to innovate, influence of the size of firm and source of capital.

The results of the regressions reveal firms' limited in-house capacity to conduct research and development activities which enable them to innovate. The acquisition of external knowledge by purchasing third-party technology services (measured in terms of marginal probability) quadruples internal research and development activities in Brazil and more than doubles them in Argentina. The introduction of product and process innovations is therefore heavily dependent on wood products (CNAE-20), pulp and paper (CNAE-21), publishing and printing (CNAE-22), non-metallic mineral products (CNAE-26), machinery and equipment (CNAE29), medical, precision and optical instruments (CNAE-33) and vehicle assembly (CNAE-34). Moreover, the sectors of wearing apparel and accessories (CNAE-18), leather and footwear (CNAE-19), chemical products (CNAE-24) and manufacture of basic metals (CNAE-27) present negative coefficients that are significant in the regression.

These results show that no clear sectoral hierarchy in process innovation exists in Brazilian and Argentine firms and point to innovative behaviour by firms themselves, rather than a propensity to innovate arising from their structural-sectoral integration. Furthermore, many firms from sectors that proved to be more innovative than the food products and beverages sector in terms of product innovations, did not excel in terms of process innovation.

the purchase of R\&D; licensing; know-how acquisition, patents and registered trademarks; consulting services, and technology transfer agreements.

As regards the differences in importance between product innovation determinants and process innovation determinants, the coefficients of these variables of innovative effort can be seen to reflect the rewards deriving from each effort because the variables are a proportion of the overall effort. In the case of product innovation, the acquisition of disembodied knowledge by means of the various types of expenditure is more significant than in the case of processes. Although the general indicators of internal research and development effort (intensity and assigned personnel) are statistically significant, as expected, they have little influence on the introduction of innovations by Brazilian and Argentine firms.

In addition to the variables directly related to expenditure on external and internal acquisition of technological knowledge, firms' external trade integration is highly important for innovation in both countries, albeit much more so for Argentine firms. The effect of exports is significant in both types of innovation in Argentina and Brazil, even though its relative importance 
differs in the two countries: whereas in Brazil exports are very important for firms' product innovation, in Argentina they are more important in process innovation. It was established that imports tend to have a positive and significant effect on innovation in both countries, which is consistent with an industrialization process in Latin American countries that was based on import substitution and the large-scale purchase of foreign capital goods and equipment. A point of note is that, in Brazil, imports are more significant for firms that introduce process innovations.

As regards structural and performance variables, market concentration, while significant, does little to explain innovation in Brazilian and Argentine firms, whereas company size has a much greater influence on both product and process innovation in the two countries. While productivity presents positive and significant coefficients, it scarcely influences Brazilian and Argentine firms.

Source of capital is an important factor in the innovative behaviour of Brazilian firms, especially in the case of products. Based on the study results and on information from specialized literature, the finding is that multinational companies located in Brazil have more propensity to innovate than domestic firms, even though this is not reflected in the decision to invest in research and development. This means that multinational companies make a limited contribution to national technological development because, even though they allow international technology transfer, they fail to promote the country's innovative capacity by creating local externalities (something that would be achieved if research and development activities were conducted locally).

In Argentina, however, foreign-sourced capital reduces the likelihood that firms will innovate. This finding is consistent with other studies that reveal that the subsidiaries of multinationals have created few technological externalities, owing to the small scale of their innovative activities and their limited technology links with local suppliers and research centres.

In sectoral terms, the results confirm a heterogeneous mix of technology intensity indicators and patterns of technology effort that is characteristic of Latin American countries. Although a few differences exist between the sectors that are more likely to innovate in both Argentina and Brazil, the study revealed the presence of a few sectors that do not tend to have greater technological opportunities in developed countries or are classified by the Organisation for Economic Co-operation and Development as low or medium technology intensity. This stems from both the technology dynamic of developing countries (dictated by traditional sectors and by large-scale production sectors based on low value-added exports) and the very concept of innovation: for the most part, products and processes are new only in the domestic market because they are copies (with or without adaptation) of products and processes already introduced into technologically advanced countries.

In general, a comparison of the results in recent years with those of the import substitution period reveals some modest advances in the patterns of innovation of Argentine and Brazilian firms. The first advance is in their means for acquiring knowledge for innovation: there has been a move away from the simple purchase of (mostly imported) machinery and equipment to the acquisition of more intangible disembodied knowledge in the form of R\&D and of other more definitive forms of technological knowledge, such as patents, licences and know-how. Expenditure on research and development activities and on industrial projects is prominent in firms' internal effort. It does not replace but rather complements their expenditure on external acquisition of knowledge. Progress in firms' pattern of innovation appears to be greater in Brazil than in Argentina, especially in the case of product innovation.

The second advance is in the role played by exports in promoting innovation: exports are more important than imports for Brazilian firms introducing product innovations. This is a powerful indication that the traditional function of exports (to generate import capacity) is changing to one of feeding back dynamic increasing returns. Owing to the positive effects of competitive pressure, exports promote better product quality, lower costs, access to opportunities for international intercompany learning and an expanded market for domestic firms, allowing them to exploit economies of scale and increase the division of labour. 
Bibliography

Amsden, A.H. (1989): Asia's Next Giant: South Korea and Late Industrialization, New York, Oxford University Press.

Araújo, R.D. (2005): Esforços tecnológicos das firmas transnacionais e domésticas, in J.A. de Negri and M.S. Salermo (orgs.), Inovações, padrões tecnológicos e desempenho das firmas industriais brasileiras, Brasilia, Institute of Applied Economic Research (IPEA).

Bell, M. (1984): 'Learning' and the accumulation of industrial technological capacity in developing countries, in M. Fransman and K. King (eds.), Technological Capability in the Third World, Hong Kong, Macmillan.

Bell, M. and K. Pavitt (1993): Technological accumulation and industrial growth:contrast between developed and developing countries, Industrial and Corporate Change, vol. 2, No. 2, Oxford, Oxford University Press.

Bernard, A. and J.B. Jensen (1999): Exceptional exporter performance: cause, effect, or both?, Journal of International Economics, vol. 47, No. 1, Amsterdam, Elsevier.

Chudnovsky, D. (1999): Science and technology policy and the National Innovation System in Argentina, CEPAL Review, No. 67, LC/G.2055-P, Santiago, Chile, April.

Chudnovsky, D., A. López and E. Orlicki (2005): Innovation and Export Performance in Argentine Manufacturing Firms, Buenos Aires, unpublished.

Chudnovsky, D., A. López and G. Pupato (2006): Innovation and productivity in developing countries: a study of Argentine manufacturing firms' behavior (1992-2001), Research Policy, vol. 35, No. 2, Amsterdam, Elsevier.

Cimoli, M. and J. Katz (2001): Structural reforms, technological gaps and economic development: a Latin American perspective, in Nelson and Winter Conference, Aalborg. Available in http:// www.druid.dk/conferences/nw/paper1/cimoli-katz.pdf.

Dahlman, C.J. (1984): Foreign technology and indigenous technological capability in Brazil, in M. Fransman and K. King (eds.), Technological Capability in the Third World, Hong Kong, Macmillan.

Dalhman, C.J. and C. Frischtak (1993): National systems of supporting technical advance in industry: the case of Brazil, in R. Nelson (ed.), National Systems of Innovation: A Comparative Analysis, New York, Oxford University Press.

De Negri, J.A. and M.S. Salermo (orgs.) (2005): Inovações, padrões tecnológicos e desempenho das firmas industriais brasileiras, Brasilia, Institute of Applied Economic Research (IPEA).

Fransman, M. (1985): Conceptualizing technical change in the Third World in the 1980s: an interpretive survey, Journal of Development Studies, vol. 21, No. 4, Londres, Taylor \& Francis, July.

Furtado, C. (1968): Subdesarrollo y estancamiento em América Latina, Buenos Aires, EUDEBA.

Greene, W.H. (2003): Econometric Analysis, Upper Saddle River, N.J., Prentice Hall.

Gujarati, D. (2004): Basic Econometrics, Boston, McGraw-Hill.

Hausman, J.A. (1978): Specification tests in econometrics, Econometrica, vol. 46, No. 6, New York, The Econometric Society.

IBGE (Brazilian Geographical and Statistical Institute) (2002): Pesquisa industrial: inovação tecnológica 2000, Rio de Janeiro.
INDEC/SECYT/ECLAC (National Institute of Statistics and Censuses/ Secretaría de Ciencia, Tecnología e Innovación Productiva/ Economic Commission for Latin América and the Caribbean) (2003): Segunda Encuesta Nacional de Innovación y Conducta Tecnológica de las Empresas Argentinas 1998-2001, Buenos Aires.

Katz, J. and N. Bercovich (1993): National systems of innovations supporting technical advance in industry: the case of Argentina, in R. Nelson (ed.), National Systems of Innovation: A Comparative Analysis, New York, Oxford University Press.

Klevorick, A.K., R.C. Levin and others (1995): On the sources and significance of interindustry differences in technological opportunities, Research Policy, vol. 24, No. 2, Amsterdam, Elsevier, March.

Lall, S. (1992): Technological capabilities and industrialization, World Development, vol. 20, No. 2, Amsterdam, Elsevier, February.

Mansfield, E. (1974): Technology and technological change, in J.H. Dunning (ed.), Economic Analysis and the Multinational Enterprise, London, George Allen \& Unwin.

Mello, J.M.C. (1982): Capitalismo tardio: contribuição a revisão critica da formação e do desenvolvimento da economia brasileira, São Paulo, Brasiliense.

Okimoto, D.I. (1989): Between MITI and the Market: Japanese Industrial Policy for High Technology, Stanford, Stanford University Press.

Pamukcu, T. (2003): Trade liberalization and innovation decisions of firms: lessons from post-1980 Turkey, World Development, vol. 31, No. 8, Amsterdam, Elsevier, August.

Pavitt, K. (1984): Sectoral patterns of technical change: towards a taxonomy and a theory, Research Policy, vol. 13, No. 6, Amsterdam, Elsevier.

Ranis, G. (1984): Determinants and consequences of indigenous technological activity, in M. Fransman and K. King (eds.), Technological Capability in the Third World, Hong Kong, Macmillan.

Rodrigues, O. (1981): Teoria do subdesenvolvimento da CEPAL, Rio de Janeiro, Forense Universitária.

Rosenberg, N. (1976): Perspectives on Technology, Cambridge, Cambridge University Press.

Scherer, F.M. (1965): Firm size, market structure, opportunity, and the output of patented inventions, American Economic Review, vol. 55, No. 5, Nashville, Tennessee, American Economic Association.

Schumpeter, J.A. (1961): Capitalismo, socialismo e democracia, Ri de Janeiro, Fundo de Cultura.

Shea, J. (1997): Instrument relevance in multivariate linear models: a simple measure, Review of Economics and Statistics, vol. 79, No. 2, Cambridge, Massachusetts, The MIT Press, May.

STATA (2005): STATA Base Reference Manual, vol. 1, College Station.

Tavares, M.C. (1978): Da substituição de importações ao capitalismo financeiro: ensaios sobre economia brasileira, Rio de Janeiro, Zahar.

(2000): Auge e declínio do processo de substituição de importações no Brasil, in R. Bielschowsky (org.), Cinqüenta anos de pensamento na CEPAL, Rio de Janeiro, Record. 
Teitel, S. and F.E. Thoumi (1986): From import substitution to exports: the manufacturing exports experience of Argentina and Brazil, Economic Development and Cultural Change, vol. 34, No. 3, Chicago, University of Chicago Press, April.

Viotti, E.B. (2002): National learning systems: a new approach on technological change in late industrializing economies and evidences from the cases of Brazil and South Korea, Technological Forecasting and Social Change, vol. 69, No. 7, Amsterdam, Elsevier, September.

Wooldridge, J.M. (2002): Econometric Analysis of Cross Section and Panel Data, Cambridge, United Kingdom, The MIT Press.

APPENDIX A

TABLE A.1

Brazil: correlation matrix for the sample of firms, $2000^{\mathrm{a}}$

(Sample: 6710 firms)

\begin{tabular}{|c|c|c|c|c|c|c|c|c|c|c|c|}
\hline & $\begin{array}{l}\text { Import } \\
\text { coef- } \\
\text { ficient }\end{array}$ & $\begin{array}{l}\text { Produc- } \\
\text { tivity }\end{array}$ & $\begin{array}{l}\text { Concen- } \\
\text { tration }\end{array}$ & $\begin{array}{c}\mathrm{R} \& \mathrm{D} \\
\text { personnel }\end{array}$ & $\begin{array}{c}\mathrm{R} \& \mathrm{D} \\
\text { intensity }\end{array}$ & $R \& D$ & $\begin{array}{c}\text { External } \\
\text { R\&D }\end{array}$ & Other & Machinery & $\begin{array}{l}\text { Industrial } \\
\text { projects }\end{array}$ & $\begin{array}{l}\text { Export } \\
\text { coef- } \\
\text { ficient }\end{array}$ \\
\hline Import coefficient & 1 & & & & & & & & & & \\
\hline Productivity & 0.42 & 1 & & & & & & & & & \\
\hline Concentration & 0.24 & 0.34 & 1 & & & & & & & & \\
\hline R\&D personnel & 0.12 & 0.12 & 0.12 & 1 & & & & & & & \\
\hline$R \& D$ intensity & 0.09 & 0.03 & 0.07 & 0.55 & 1 & & & & & & \\
\hline $\mathrm{R} \& \mathrm{D}$ & 0.12 & 0.11 & 0.12 & 0.49 & 0.53 & 1 & & & & & \\
\hline External R\&D & 0.07 & 0.06 & 0.17 & 0.20 & 0.15 & 0.12 & 1 & & & & \\
\hline Other & 0.10 & 0.10 & 0.13 & 0.12 & 0.10 & 0.10 & 0.12 & 1 & & & \\
\hline Machinery & 0.08 & 0.06 & 0.08 & 0.07 & 0.01 & -0.11 & 0.03 & 0.05 & 1 & & \\
\hline Industrial projects & 0.10 & 0.11 & 0.07 & 0.18 & 0.15 & 0.09 & 0.09 & 0.14 & 0.17 & 1 & \\
\hline Export coefficient & 0.05 & 0.05 & 0.12 & 0.00 & 0.13 & 0.01 & 0.04 & 0.05 & 0.05 & 0.04 & 1 \\
\hline
\end{tabular}

Source: author.

TABLE A.2

Argentina: correlation matrix for the sample of firms, 2001 (Sample $=1286$ firms)

\begin{tabular}{|c|c|c|c|c|c|c|c|c|c|c|c|}
\hline & $\begin{array}{l}\text { Import } \\
\text { coef- } \\
\text { ficient }\end{array}$ & $\begin{array}{l}\text { Produc- } \\
\text { tivity }\end{array}$ & $\begin{array}{c}\text { Concen- } \\
\text { tration }\end{array}$ & $\begin{array}{c}\text { R\&D } \\
\text { personnel }\end{array}$ & $\begin{array}{c}\text { R\&D } \\
\text { intensity }\end{array}$ & $\mathrm{R} \& \mathrm{D}$ & $\begin{array}{c}\text { External } \\
\text { R\&D }\end{array}$ & Other & Machinery & $\begin{array}{l}\text { Industrial } \\
\text { projects }\end{array}$ & $\begin{array}{c}\text { Export } \\
\text { coef- } \\
\text { ficient }\end{array}$ \\
\hline Import coefficient & 1 & & & & & & & & & & \\
\hline Productivity & 0.31 & 1 & & & & & & & & & \\
\hline Concentration & 0.26 & 0.26 & 1 & & & & & & & & \\
\hline R\&D personnel & 0.11 & 0.15 & 0.03 & 1 & & & & & & & \\
\hline $\mathrm{R} \& \mathrm{D}$ intensity & 0.10 & 0.01 & 0.10 & 0.22 & 1 & & & & & & \\
\hline $\mathrm{R} \& \mathrm{D}$ & 0.09 & 0.05 & 0.09 & 0.24 & 0.56 & 1 & & & & & \\
\hline External R\&D & -0.03 & 0.05 & 0.07 & 0.17 & 0.09 & 0.09 & 1 & & & & \\
\hline Other & 0.11 & 0.11 & 0.12 & 0.12 & 0.13 & 0.08 & 0.08 & 1 & & & \\
\hline Machinery & 0.14 & 0.16 & 0.09 & 0.09 & -0.02 & -0.12 & 0.02 & 0.01 & 1 & & \\
\hline Industrial projects & 0.08 & 0.07 & 0.13 & 0.12 & 0.09 & 0.09 & 0.09 & 0.03 & -0.03 & 1 & \\
\hline Export coefficient & 0.09 & 0.08 & 0.08 & 0.06 & 0.04 & -0.01 & 0.03 & 0.05 & 0.09 & 0.03 & 1 \\
\hline
\end{tabular}

Source: author.

a $\quad$ \&\&D $=$ research and development. 
APPENDIX B

Brazil's standard national classification of economic activities (CNAE) devised by the Brazilian Geographical and Statistical Institute (IBGE)

\begin{tabular}{ll}
\hline Division & \\
\hline 15 & Manufacture of food products and beverages \\
16 & Manufacture of tobacco products \\
17 & Manufacture of textile products \\
18 & Manufacture of wearing apparel and accessories \\
19 & Tanning and dressing of leather and manufacture of leather articles, luggage and footwear \\
20 & Manufacture of wood products \\
21 & Manufacture of pulp, paper and paper products \\
22 & Publishing, printing and reproduction of recorded media \\
23 & Manufacture of coke and refined petroleum products and nuclear fuel \\
24 & and alcohol production \\
25 & Manufacture of chemical products \\
26 & Manufacture of rubber and plastic products \\
27 & Manufacture of non-metallic mineral products \\
28 & Manufacture of basic metals \\
29 & Manufacture of fabricated metal products - except machinery and equipment \\
30 & Manufacture of machinery and equipment \\
31 & Manufacture of office machinery and computers \\
32 & Manufacture of electrical machinery, apparatus and supplies \\
33 & Manufacture of electronic and communication equipment and apparatus \\
34 & Manufacture of medical and hospital equipment, precision and optical instruments, \\
35 & industrial automation equipment, watches and clocks \\
36 & Manufacture and assembly of motor vehicles, trailers and bodywork \\
& Manufacture of other transport equipment \\
\hline & Manufacture of furniture and miscellaneous manufacturing \\
\hline
\end{tabular}


APPENDIX C

TABLE C.1

Brazil (product innovation): results of phase one of the probit regression for the export coefficient, $2000^{\mathrm{a}}$

\begin{tabular}{|c|c|c|}
\hline Explanatory variables & Coefficient & Standard deviation \\
\hline Import coefficient & $-0.15^{* * *}$ & 0.02 \\
\hline Productivity & $0.00 * * *$ & 0.00 \\
\hline Concentration & $-0.49^{\mathrm{NS}}$ & 0.44 \\
\hline Personnel assigned to $\mathrm{R} \& \mathrm{D}$ & $-0.00^{\mathrm{NS}}$ & 0.00 \\
\hline $\mathrm{R} \& \mathrm{D}$ intensity & $-0.00^{\mathrm{NS}}$ & 0.00 \\
\hline Internal R\&D effort & $-0.03 * * *$ & 0.01 \\
\hline Purchase of R\&D & $-0.05^{\mathrm{NS}}$ & 0.06 \\
\hline Expenditure on external knowledge & $0.02^{\mathrm{NS}}$ & 0.03 \\
\hline Expenditure on machinery & $0.01 * * *$ & 0.00 \\
\hline Expenditure on industrial projects & $-0.03 *$ & 0.01 \\
\hline Dummy variable for source of capital & $0.04 * * *$ & 0.01 \\
\hline Dummy variable for medium-sized firms & $-0.02 * * *$ & 0.00 \\
\hline Dummy variable for large firms & $-0.02 * * *$ & 0.01 \\
\hline CNAE-16 & $0.08 * * *$ & 0.03 \\
\hline CNAE-17 & $-0.03 * * *$ & 0.01 \\
\hline CNAE-18 & $-0.01^{\mathrm{NS}}$ & 0.00 \\
\hline CNAE-19 & $0.05^{* * *}$ & 0.01 \\
\hline CNAE-20 & $0.09 * * *$ & 0.01 \\
\hline CNAE-21 & $-0.04 * * *$ & 0.01 \\
\hline CNAE-22 & $-0.03 * * *$ & 0.01 \\
\hline CNAE-23 & $-0.03 *$ & 0.02 \\
\hline CNAE-24 & $-0.05 * * *$ & 0.01 \\
\hline CNAE-25 & $-0.05 * * *$ & 0.01 \\
\hline CNAE-26 & $-0.01 * * *$ & 0.00 \\
\hline CNAE-27 & $-0.02 * * *$ & 0.01 \\
\hline CNAE-28 & $-0.04 * * *$ & 0.01 \\
\hline CNAE-29 & $-0.04 * * *$ & 0.01 \\
\hline CNAE-31 & $-0.05 * * *$ & 0.01 \\
\hline CNAE-32 & $-0.05 * * *$ & 0.01 \\
\hline CNAE-33 & $-0.01^{\mathrm{NS}}$ & 0.01 \\
\hline CNAE-34 & $-0.03 * * *$ & 0.01 \\
\hline CNAE-35 & $-0.02^{\mathrm{NS}}$ & 0.02 \\
\hline Dummy variable for exports in 1997 & $0.06^{* * *}$ & 0.00 \\
\hline GDP growth & $0.14 * * *$ & 0.00 \\
\hline Constant & $0.01 * * *$ & 0.00 \\
\hline Wald statistic ${ }^{b}$ & & \\
\hline Sargan statistic ${ }^{c}$ & & \\
\hline Hausman statistic ${ }^{\mathrm{d}}$ & & \\
\hline Partial R² (Shea) & & \\
\hline
\end{tabular}

Source: author, on the basis of the SAS programme.

a $\quad \mathrm{R} \& \mathrm{D}=$ research and development. CNAE $=$ Brazil's standard national classification of economic activities.

b Wald test for exogeneity of the export coefficient.

c Sargan test for validity of the instruments.

d Hausman test for exogeneity of the export coefficient variable.

* Significant to $10 \%$. ** Significant to $5 \%$. *** Significant to $1 \%$. NS $=$ not significant. 
TABLE C. 2

Argentina (product innovation): results of phase one of the probit regression for the export coefficient, $2001^{a}$

\begin{tabular}{|c|c|c|}
\hline Explanatory variables & Coefficient & Standard deviation \\
\hline Import coefficient & $0.03^{\mathrm{NS}}$ & 0.02 \\
\hline Productivity & $0.00 *$ & 0.00 \\
\hline Concentration & $-0.39^{\mathrm{NS}}$ & 0.28 \\
\hline Personnel assigned to R\&D) & $0.00 * * *$ & 0.00 \\
\hline R\&D intensity & $0.00^{\mathrm{NS}}$ & 0.00 \\
\hline Internal $\mathrm{R} \& \mathrm{D}$ effort & $-0.07 * * *$ & 0.01 \\
\hline Purchase of R\&D & $-0.17 * * *$ & 0.05 \\
\hline Expenditure on external knowledge & $-0.05^{\mathrm{NS}}$ & 0.09 \\
\hline Expenditure on machinery & $-0.03 * * *$ & 0.00 \\
\hline Expenditure on industrial projects & $-0.07 * * *$ & 0.02 \\
\hline Dummy variable for source of capital & $0.03 * * *$ & 0.01 \\
\hline Dummy variable for medium-sized firms & $0.01 * * *$ & 0.01 \\
\hline Dummy variable for large firms & $-0.01^{\mathrm{NS}}$ & 0.02 \\
\hline CNAE-16 & $0.45 * * *$ & 0.08 \\
\hline CNAE-17 & $0.00^{\mathrm{NS}}$ & 0.01 \\
\hline CNAE-18 & $-0.01^{\mathrm{NS}}$ & 0.01 \\
\hline CNAE-19 & $0.12 * * *$ & 0.01 \\
\hline CNAE-20 & $-0.01^{\mathrm{NS}}$ & 0.01 \\
\hline CNAE-21 & $-0.06^{* * * *}$ & 0.01 \\
\hline CNAE-22 & $-0.03 * * *$ & 0.01 \\
\hline CNAE-23 & $0.10^{\mathrm{NS}}$ & 0.07 \\
\hline CNAE-24 & $-0.08 * * *$ & 0.01 \\
\hline CNAE-25 & $0.03 *$ & 0.01 \\
\hline CNAE-26 & $-0.03 * * *$ & 0.01 \\
\hline CNAE-27 & $0.02 * *$ & 0.01 \\
\hline CNAE-28 & $-0.02 *$ & 0.01 \\
\hline CNAE-29 & $-0.01^{\mathrm{NS}}$ & 0.02 \\
\hline CNAE-31 & $-0.03 *$ & 0.02 \\
\hline CNAE-32 & $-0.03^{\mathrm{NS}}$ & 0.05 \\
\hline CNAE-33 & $-0.03^{\mathrm{NS}}$ & 0.05 \\
\hline CNAE-34 & $0.05^{* *}$ & 0.03 \\
\hline CNAE-35 & $0.03^{\mathrm{NS}}$ & 0.03 \\
\hline Dummy variable for exports in 1997 & $0.21 * * *$ & 0.00 \\
\hline GDP growth & $0.12^{\mathrm{NS}}$ & 1.20 \\
\hline Constant & $-0.12^{\mathrm{NS}}$ & 1.31 \\
\hline Wald statistic ${ }^{\mathrm{b}}$ & & \\
\hline Sargan statistic ${ }^{c}$ & & \\
\hline Hausman statistic ${ }^{\mathrm{d}}$ & & \\
\hline Partial R ${ }^{2}$ (Shea) & & \\
\hline
\end{tabular}

Source: author, on the basis of the SAS programme.

a $\quad \mathrm{R} \& \mathrm{D}=$ research and development. CNAE $=$ Brazil's standard national classification of economic activities.

b Wald test for exogeneity of the export coefficient.

c Sargan test for validity of the instruments.

d Hausman test for exogeneity of the export coefficient variable.

* Significant to $10 \%$; * Significant to $5 \%$. *** Significant to $1 \%$. NS $=$ not significant. 
TABLE C.3

Brazil (process innovation): results of phase one

of the probit regression for the export coefficient, $2000^{\text {a }}$

\begin{tabular}{|c|c|c|}
\hline Explanatory variables & Coefficient & Standard deviation \\
\hline Import coefficient & $-0.15^{* * *}$ & 0.02 \\
\hline Productivity & $0.00^{* * * *}$ & 0.00 \\
\hline Concentration & $-0.50^{\mathrm{NS}}$ & 0.44 \\
\hline Personnel assigned to $\mathrm{R} \& \mathrm{D}$ & $-0.00^{\mathrm{NS}}$ & 0.00 \\
\hline $\mathrm{R} \& \mathrm{D}$ intensity & $-0.00^{\mathrm{NS}}$ & 0.00 \\
\hline Internal R\&D effort & $-0.03 * * *$ & 0.01 \\
\hline Purchase of $R \& D$ & $-0.05^{\mathrm{NS}}$ & 0.06 \\
\hline Expenditure on external knowledge & $0.03^{\mathrm{NS}}$ & 0.03 \\
\hline Expenditure on machinery & $0.01 * * *$ & 0.00 \\
\hline Expenditure on industrial projects & $-0.03 *$ & 0.01 \\
\hline Dummy variable for source of capital & $0.04 * * *$ & 0.01 \\
\hline Dummy variable for medium-sized firms & $-0.02 * * *$ & 0.00 \\
\hline Dummy variable for large firms & $-0.02 * * *$ & 0.01 \\
\hline CNAE-16 & $0.08 * * *$ & 0.03 \\
\hline CNAE-17 & $-0.03 * * *$ & 0.01 \\
\hline CNAE-18 & $-0.01^{\mathrm{NS}}$ & 0.00 \\
\hline CNAE-19 & $0.05^{* * *}$ & 0.01 \\
\hline CNAE-20 & $0.09 * * *$ & 0.01 \\
\hline CNAE-21 & $-0.04 * * *$ & 0.01 \\
\hline CNAE-22 & $-0.03 * * *$ & 0.01 \\
\hline CNAE-23 & $-0.03 *$ & 0.02 \\
\hline CNAE-24 & $-0.05^{* * *}$ & 0.01 \\
\hline CNAE-25 & $-0.05 * * *$ & 0.01 \\
\hline CNAE-26 & $-0.01 * * *$ & 0.00 \\
\hline CNAE-27 & $-0.02 * * *$ & 0.01 \\
\hline CNAE-28 & $-0.04 * * *$ & 0.01 \\
\hline CNAE-29 & $-0.04 * * *$ & 0.01 \\
\hline CNAE-31 & $-0.04 * * *$ & 0.01 \\
\hline CNAE-32 & $-0.05 * * *$ & 0.01 \\
\hline CNAE-33 & $-0.01^{\mathrm{NS}}$ & 0.01 \\
\hline CNAE-34 & $-0.03 * * *$ & 0.01 \\
\hline CNAE-35 & $-0.02^{\mathrm{NS}}$ & 0.02 \\
\hline Dummy variable for exports in 1997 & $0.06^{* * *}$ & 0.00 \\
\hline GDP growth & $0.14 * * *$ & 0.00 \\
\hline Constant & $0.01 * * *$ & 0.00 \\
\hline Wald statistic ${ }^{b}$ & \multicolumn{2}{|c|}{$19.10 * * *$} \\
\hline Sargan statistic ${ }^{c}$ & \multicolumn{2}{|c|}{$2.09^{\mathrm{NS}}$} \\
\hline Hausman statistic ${ }^{\mathrm{d}}$ & \multicolumn{2}{|c|}{$12.13 * * *$} \\
\hline Partial R ${ }^{2}$ (Shea) & \multicolumn{2}{|c|}{0.13} \\
\hline
\end{tabular}

Source: author, on the basis of the SAS programme.

a $\quad \mathrm{R} \& \mathrm{D}=$ research and development. CNAE $=$ Brazil's standard national classification of economic activities.

b Wald test for exogeneity of the export coefficient.

c Sargan test for validity of the instruments.

d Hausman test for exogeneity of the export coefficient variable.

* Significant to $10 \%$. ** Significant to $5 \%$. *** Significant to $1 \%$. NS $=$ not significant. 
TABLE C. 4

Argentina (process innovation): results of phase one of the probit regression for the export coefficient, $2001^{\text {a }}$

\begin{tabular}{|c|c|c|}
\hline Explanatory variables & Coefficient & Standard deviation \\
\hline Import coefficient & $0.03^{\mathrm{NS}}$ & 0.02 \\
\hline Productivity & $0.00^{*}$ & 0.00 \\
\hline Concentration & $-0.39^{\mathrm{NS}}$ & 0.28 \\
\hline Personnel assigned to $R \& D$ & $0.00 * * *$ & 0.00 \\
\hline R\&D intensity & $0.00^{\mathrm{NS}}$ & 0.00 \\
\hline Internal R\&D effort & $-0.07 * * *$ & 0.01 \\
\hline Purchase of R\&D & $-0.17 * * *$ & 0.05 \\
\hline Expenditure on external knowledge & $-0.05^{\mathrm{NS}}$ & 0.09 \\
\hline Expenditure on machinery & $-0.03 * * *$ & 0.00 \\
\hline Expenditure on industrial projects & $-0.07 * * *$ & 0.02 \\
\hline Dummy variable for source of capital & $0.03 * * *$ & 0.01 \\
\hline Dummy variable for medium-sized firms & $0.01 * * *$ & 0.01 \\
\hline Dummy variable for large firms & $-0.01^{\mathrm{NS}}$ & 0.02 \\
\hline CNAE-16 & $0.45 * * *$ & 0.08 \\
\hline CNAE-17 & $0.00^{\mathrm{NS}}$ & 0.01 \\
\hline CNAE-18 & $-0.01^{\mathrm{NS}}$ & 0.01 \\
\hline CNAE-19 & $0.12 * * *$ & 0.01 \\
\hline CNAE-20 & $-0.01^{\mathrm{NS}}$ & 0.01 \\
\hline CNAE-21 & $-0.06 * * *$ & 0.01 \\
\hline CNAE-22 & $-0.03 * * *$ & 0.01 \\
\hline CNAE-23 & $0.10^{\mathrm{NS}}$ & 0.07 \\
\hline CNAE-24 & $-0.08 * * *$ & 0.01 \\
\hline CNAE-25 & $0.03^{*}$ & 0.01 \\
\hline CNAE-26 & $-0.03 * * *$ & 0.01 \\
\hline CNAE-27 & $0.02 * *$ & 0.01 \\
\hline CNAE-28 & $-0.02 *$ & 0.01 \\
\hline CNAE-29 & $-0.01^{\mathrm{NS}}$ & 0.02 \\
\hline CNAE-31 & $-0.03 *$ & 0.02 \\
\hline CNAE-32 & $-0.03^{\mathrm{NS}}$ & 0.05 \\
\hline CNAE-33 & $-0.03^{\mathrm{NS}}$ & 0.05 \\
\hline CNAE-34 & $0.05^{* *}$ & 0.03 \\
\hline CNAE-35 & $0.03^{\mathrm{NS}}$ & 0.03 \\
\hline Dummy variable for exports in 1997 & $0.21 * * *$ & 0.00 \\
\hline GDP growth & $0.12^{\mathrm{NS}}$ & 1.20 \\
\hline Constant & $-0.12^{\mathrm{NS}}$ & 1.31 \\
\hline Wald statistic ${ }^{\mathrm{b}}$ & & \\
\hline Sargan statistic ${ }^{c}$ & & \\
\hline Hausman statistic ${ }^{\mathrm{d}}$ & & \\
\hline Partial R² (Shea) & & \\
\hline
\end{tabular}

Source: author, on the basis of the SAS programme.

a $\quad \mathrm{R} \& \mathrm{D}=$ research and development. CNAE $=$ Brazil's standard national classification of economic activities.

b Wald test for exogeneity of the export coefficient.

c Sargan test for validity of the instruments.

d Hausman test for exogeneity of the export coefficient variable.

* Significant to $10 \%$. ** Significant to $5 \%$. *** Significant to $1 \%$. NS $=$ not significant. 